\title{
WestVirginiaUniversity
}

THE RESEARCH REPOSITORY @ WVU

Graduate Theses, Dissertations, and Problem Reports

2006

\section{Diesel fuel extender from animal waste}

Laura S. Eddy

West Virginia University

Follow this and additional works at: https://researchrepository.wvu.edu/etd

\section{Recommended Citation}

Eddy, Laura S., "Diesel fuel extender from animal waste" (2006). Graduate Theses, Dissertations, and Problem Reports. 2355.

https://researchrepository.wvu.edu/etd/2355

This Thesis is protected by copyright and/or related rights. It has been brought to you by the The Research Repository @ WVU with permission from the rights-holder(s). You are free to use this Thesis in any way that is permitted by the copyright and related rights legislation that applies to your use. For other uses you must obtain permission from the rights-holder(s) directly, unless additional rights are indicated by a Creative Commons license in the record and/ or on the work itself. This Thesis has been accepted for inclusion in WVU Graduate Theses, Dissertations, and Problem Reports collection by an authorized administrator of The Research Repository @ WVU. For more information, please contact researchrepository@mail.wvu.edu. 


\title{
Diesel Fuel ExtendeR fRom ANimal WASte
}

\author{
Laura S Eddy \\ Thesis submitted to the \\ College of Engineering and Mineral Resources \\ at \\ West Virginia University \\ in partial fulfillment of the requirements for the degree of
}

\section{Master of Science in Chemical Engineering}

\author{
Presented to: \\ Dr. Alfred H. Stiller, Chair \\ Dr. Eric Johnson \\ Dr. Joseph A. Shaeiwitz \\ Dr. Eugene E. D. Felton \\ Department of Chemical Engineering
}

Morgantown, West Virginia

2006

Keywords: Animal Waste, BioFuel, Diesel Fuel Extender

Copyright 2006 Laura Eddy 


\section{ABSTRACT \\ Diesel Fuel Extender from Animal Waste \\ LAURA EDDY}

An increase in the quantity of food is required to meet the demand of an increasing in the population. The agricultural industry continues to grow to meet this demand. This thesis focuses on a new method to deal with the increasing amount of animal waste that is produced as a result of the increasing food demand. By reacting animal waste with an aqueous solution and diesel fuel, a major fraction of the waste becomes a diesel fuel extender. The extended diesel fuel contains no ash and has a viscosity similar to conventional diesel fuel. The extended diesel fuel contains $20 \%$ dissolved hog manure produced by reaction with an aqueous solution of $40 \%$ propanol and $60 \%$ water. Initial experiments have shown that the extended diesel fuel can be run in a diesel engine with no modifications.

There are four products from the reaction: (1) a gas that is about $95 \%$ carbon dioxide, (2) the extended diesel fuel described above (3) an aqueous solution that contains small chain polar organic molecules and (4) a solid phase. The remaining aqueous phase contains a mixture of small chain organic acid and alcohols in water. If the aqueous phase contains less then $50 \%$ water, it also has a heating value. The separation of the water and organic alcohols and acids should be researched; it could have potential fuel applications. The ash material is removed as water-soluble and water-insoluble phosphate salts. The insoluble solid material also has a heating value of about 10,000-12,000 BTU/lb and could have potential fuel applications. With the 
exception of the gas produced, each product of the diesel fuel extender reaction could be used or recycled, creating a process with no waste streams.

The diesel fuel extender process was compared with the corn-to-ethanol process, and the best conversion process of the corn was determined. In each case, the same quantity of corn was used as the starting material. The corn was fed to finishing hogs (150lb to $280 \mathrm{lbs}$ ) in the diesel fuel extender process to create the manure. This manure was then used in the diesel fuel extender reaction. Comparisons were made based on the energy ratio, which is the amount of energy produced divided by the amount of energy required. The ethanol process had an energy ratio of 1.71 , and the diesel fuel extender process produced an energy ratio of 2.05 plus an additional 30 finishing hogs. The conclusions of this comparison indicate that by feeding the corn to finishing hogs and then converting their manure to fuel, more energy can be obtained than by the fermentation of corn and significant "free" protein is produced. 


\section{ACKNOWLEDGEMENTS}

I would like to thank my loving husband for his unending belief in my ability to succeed and for his patience during the completion of this thesis.

I would like to acknowledge Dr. Alfred Stiller, my advisor, for mentoring me throughout my research and education. He taught me to view the world thru new eyes and to see the possibilities in everything.

I would like to acknowledge my parents for instilling the value of hard work and education in my life and for allowing me to choose my own path.

I would like to acknowledge the WVU School of Agricultural Sciences for the use of their laboratories to complete this research.

I would also like to thank the NRCCE for data analysis and Jennie Wheeler for the many samples she tested and retested. 


\section{TABLE OF CONTENTS}

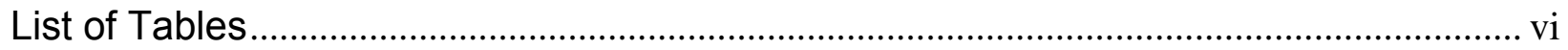

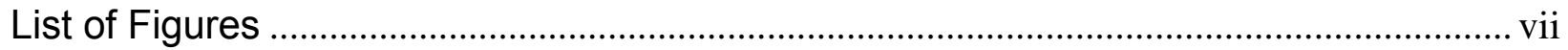

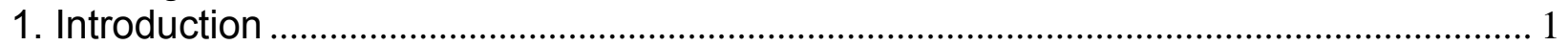

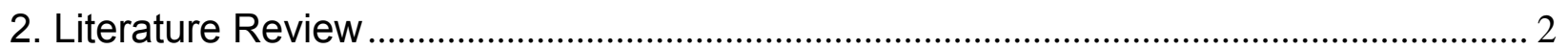

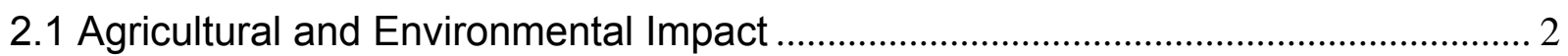

2.2 Methods for dealing with Agricultural Waste ................................................................. 3

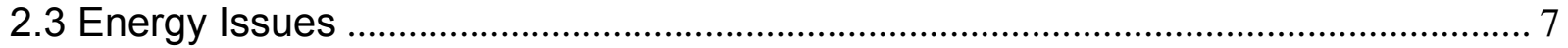

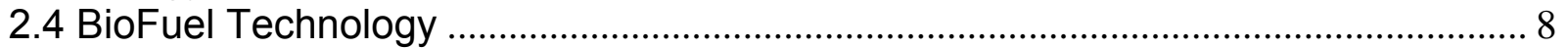

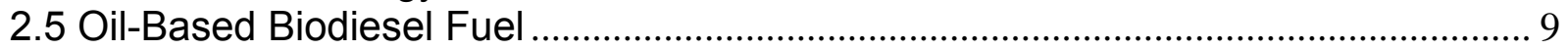

2.6 Ethanol-Based Biodiesel Fuel ............................................................................. 13

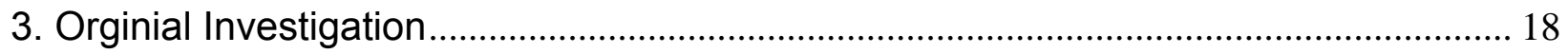

3.1 Preliminary Experiments ....................................................................................... 18

3.2 Step one: Evaluation of Conversion Potential Using Tubing Bomb Experiments. 19

3.3 Results: Tubing Bomb Experiments .......................................................................... 19

3.4 Step two: Scale up Using One-Gallon Autoclave Experiments................................. 20

3.5 Results: One Gallon Reactor Experiments............................................................. 21

3.6 Step three: Preparation and Evaluation of Processed Extended Diesel Fuel ....... 21

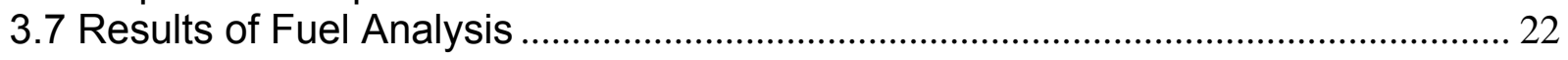

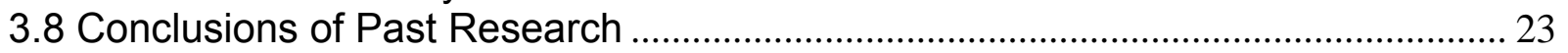

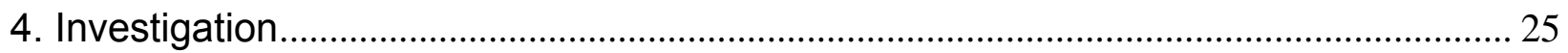

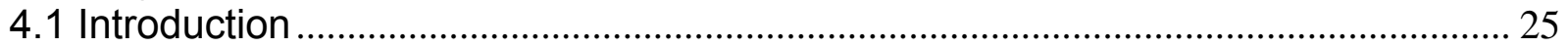

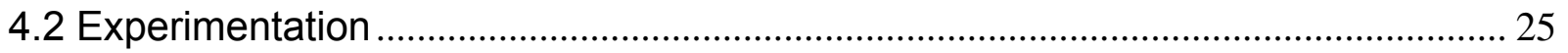

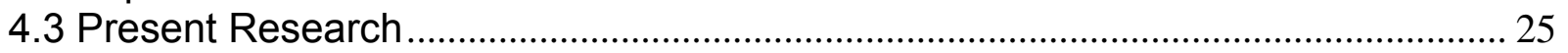

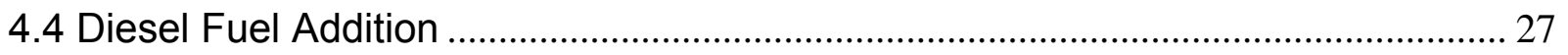

4.5 Diesel Fuel Addition with Alcohol Water Solutions ..................................................... 33

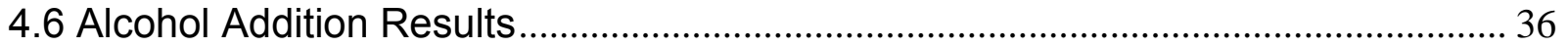

4.7 Heating Values.......................................................................................................... 37

4.8 Simulated Distillation Curves .................................................................................. 38

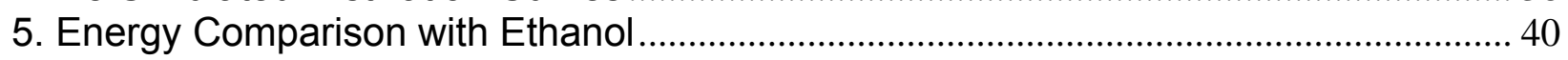

5.1 Amount of Finishing Hogs and Manure Produced ..................................................... 41

5.2 Heat Required to Reach Reaction Temperature ......................................................... 42

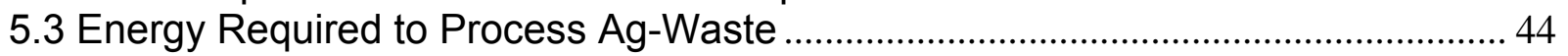

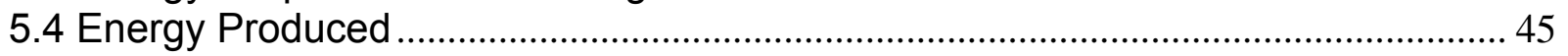

5.5 Comparison with Ethanol ............................................................................................... 46

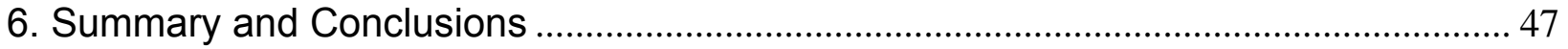

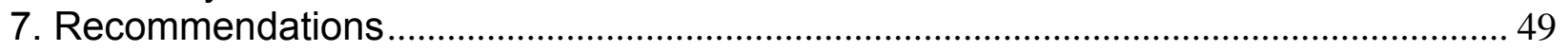

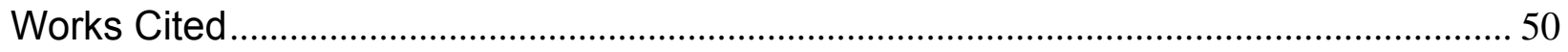

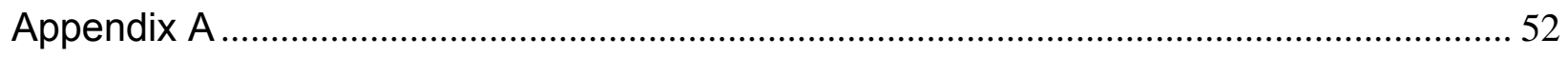

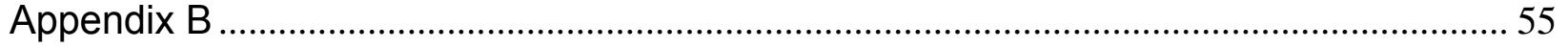

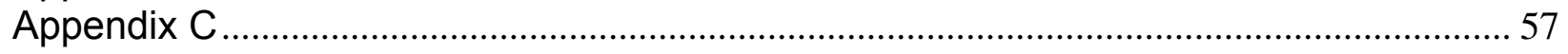

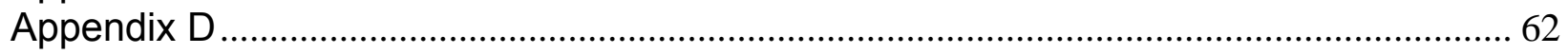

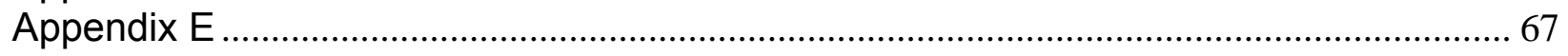




\section{LIST OF TABLES}

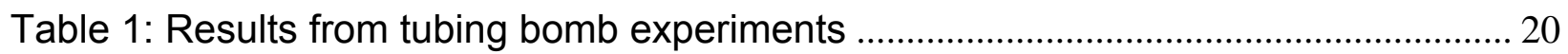

Table 2: ASTM Test Results for Original Diesel Fuel Extender.............................................. 23

Table 3: Overall Mass Balance for Diesel Fuel Extender .................................................... 29

Table 4: TGA Results on Extended Diesel Fuel, THF Insoluble, and Gray Solid Material

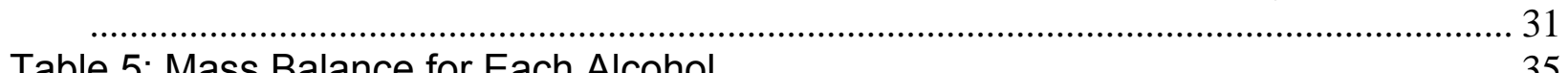

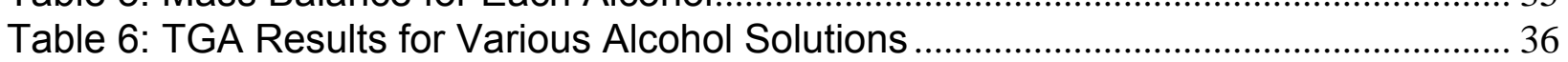

Table 7: Heating Values for the Extended Diesel Fuel, THF Insoluble Solids, and

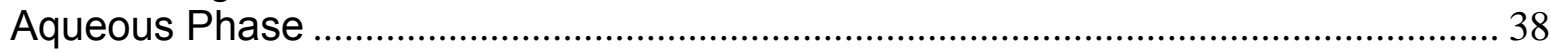

Table 8: Simulated Distillation Constants for each Extended Diesel Fuel ......................... 39

Table 9: Varying Corn Percentage for Finishing Hog Diets ................................................ 42

Table 10: Reactant amounts in Ethanol Comparison............................................................. 42

Table 11: Total Energy Required for the Production of Diesel Fuel Extender ...................4 45

Table 12: Total Energy Produced in the Production of Diesel Fuel Extender .................... 46

Table 13: Energy Comparison of Diesel Fuel Extender Process and Ethanol.................. 47 


\section{LIST OF FIGURES}

Figure 1: Process Flow Schematic for Biodiesel Production (20) ...................................... 11

Figure 2: Ethanol Dry and Wet Milling Process Flow Diagram (27).................................... 14

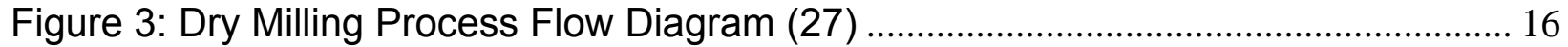

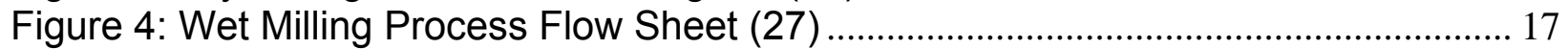

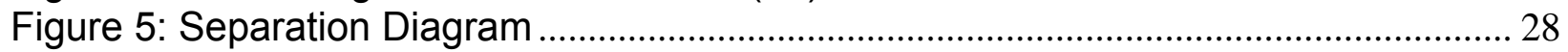

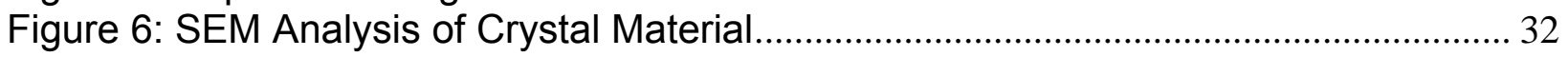

Figure 7: SEM Photograph of Crystal Material...................................................................... 32 


\section{INTRODUCTION}

Agricultural waste has become an issue of worldwide concern. It has widespread impacts on the food supply, the environment, and the world economy. The population worldwide is increasing exponentially, and the agricultural industry must develop methods to feed the enlarging population. Perhaps the most efficient method for increasing high quality protein production is through animal husbandry. One major hurdle that accompanies advances in animal production is the production of animal waste. The large quantities of nitrates and phosphates found in this waste can be devastating to the environment when it finds its way into the rivers and lakes. The agricultural economy also suffers as farmers are forced to pay to get rid of the waste or cannot produce to capacity.

In our climate of ever-rising energy requirements, we must either become more efficient in our uses and production of energy or invent new ways to make energy from different sources. This thesis reports on a method through which the animal waste could be turned into a viable fuel. This could alleviate associated problems of excess agricultural waste and simultaneously provide a new source of green energy. 


\section{LITERATURE REVIEW}

\subsection{AgRICULTURAL AND ENVIRONMENTAL IMPACT}

The agricultural industry is challenged to produce sufficient high-quality foodprotein products to meet the demands of an ever-expanding worldwide population. Currently the industry has met that demand through the production of animal-proteinbased products but has also produced one of the world's major environmental concerns. The production of animal products simultaneously produces large quantities of animal waste. One of the major categories of animal waste is manure and manure products. When animal production facilities were less concentrated, animal waste was more diffuse and could be disposed of with minimal environmental consequences by spreading it on farmland as organic fertilizers. With the advent of consolidated confinement farming operations, animal wastes are concentrated at each site, and old procedures are not practical (1). Animal waste production is commonly expressed as pounds per day per 1,000 pounds of livestock live weight (lb/d/1,000 lb) (2). A typical broiler operation or a dairy farm produces as excreted, approximately 80lb of waste/d/1,000 lb (2). Typical beef feedlot operations and swine operations produce 51.2 and $63.4 \mathrm{lb}$ of waste/d/1000lb of live weight, respectively (2). United States broiler production in 2003 (3) and inventory of dairy cows in 2002 (4) was an estimated 8.5 billion birds and 9.1 million cows, with birds averaging 4-6 lbs and cows averaging 1000-1500 lbs. There was an estimated U.S. production of 26.7 million head of feeder cattle slaughtered in 2004 averaging $1250 \mathrm{lbs}$ (5). Furthermore, in 2004, there was an estimated 102 million head of hogs slaughtered at an average live wt of $285 \mathrm{lb}$ (5). 
Thus, just from these segments of the U.S. animal agricultural industry, one can see that the amount of manure generated in the U.S. alone is staggering. High concentrations of animal manure overwhelm the need for organic fertilizer, and now are considered an environmental liability.

Areas of high agricultural waste concentrations have become the focus of several studies in which the environmental impacts of run off were measured $(6,7)$. In North Carolina alone (North Carolina Coastal Plan), studies have shown that animal waste runoff has increased the nitrogen level in the local water supply by an estimated 124,230 metric tons per year (7). Furthermore, the phosphate in the runoff has increased by 29,080 metric tons per year (7). The pollution resulting from the runoff of waste from hog production facilities in North Carolina has suspended further growth of the industry (1). This trend is becoming more common and poses a severe limitation to agricultural industrial growth.

Another environmental concern is air pollution. Areas of high agricultural waste concentrations have many volatile organic compounds emitted into the atmosphere decreasing the overall air quality (8). The compounds with the greatest potential to decrease the air quality are $\mathrm{C}_{2}$ through $\mathrm{C}_{9}$ organic acids, since they have the highest transport coefficients and airborne concentrations (8). These compounds also smell unpleasant causing problems for the surrounding homes and towns.

\subsection{Methods FOR DEALING WITH AgRICULTURAL WASTE}

Currently, there are several methods to manage animal wastes including physical, chemical, and biological processes (8). Most physical processes, including 
gravity sedimentation, filtration, or evaporation are liquid-solid separations that are primarily used to concentrate the solid waste. Chemical treatments include the use of metallic salts (10) and/or organic polymers (11) as sequestering agents. These chemical processes increase the particle size of the solids in the waste and enhance sedimentation by producing a denser concentration of solids. In many situations, physical and chemical processes are combined to increase efficiency. The resulting high concentrations of solids may then be disposed of by pyrolysis or incineration.

Biological treatment in which agricultural waste is bactrerolocially digested is also a commonly used disposal technique. Both aerobic and anaerobic digesters are used. Both methods require a lagoon, pond, or large vessel. In anaerobic digestion, the waste is treated with biological organisms that digest and reduce the waste generating methane. The methane can be captured and used as a heating fuel or as fuel for on-site power generation. In aerobic digestion, carbon dioxide is produced. In both biodigestion processes, about half of the carbon in the agricultural waste is converted to gas. The remaining half is concentrated in solid sludge sediment and must be disposed of using other means. The undigested solid slurries contain the insoluble inorganic material and settle to the bottom of the ponds. In order to maintain the viability of the lagoon, these solids must be removed, which requires a further disposal effort.

There have been a few efforts to convert agricultural waste to fuels by nonbiodigestion processes. It was hypothesized that since non-manure animal waste, such as offal, contains a high portion of organic compounds, it might be possible to convert the waste into a potential fuel. One of the most studied processes involves pyrolysis (12). In this process, animal waste is heated to a high temperature in an oxygen- 
deprived environment (12). The organic molecules are thermally cracked to smaller molecules that can reform to produce molecules that might be used as precursors for fuels (12). Wood is the oldest raw material for pyrolysis and dates back to the ancient Egyptians, Greeks, and Romans (12). They made charcoal and collected the condensable volatiles for embalming purposes and in the construction of wooden ships (12).

There are four main types of pyrolysis reactors: 1) Ovens and kilns, 2) Gravitating-Bed Process, 3) Fluidized-Bed Systems, and 4) Entrained-Flow Systems (12). These reactor types dictate the conditions of pyrolysis, thus the products and composition. Ovens and kilns operate at low heating rates and long vapor residence times creating small quantities of liquid products and high quantities of char (12). Gravitating-bed processes operate similar to a fixed-bed reactor and usually generate large amounts of gas due to the vapor residence time (12). With the high heat-transfer rates between the sand and feed particles, fluidized-bed systems have relatively high heating values and produce large quantities of liquid product (12). In entrained-flow systems, finely ground biomass is fed through a hot entrained-flow transport reactor, and heating rates are higher than the fluidized bed reactor (12). The vapor residence time is very short, giving a distribution of products: $20 \%$ char, $25 \%$ gas and $45 \%$ liquids (12).

Another method similar to pyrolysis is gasification. In gasification, the biomass is thermally degraded in the presence of controlled amounts of oxidizing agents to provide a simple gaseous phase (12). This gas phase contains hydrogen, water, carbon dioxide, methane and residues contained in the inorganic matter (12). The gasification 
reactions are highly temperature dependant and are effected by the metallic salts present in the biomass. The higher the amount of metallic salts, the lower the conversion thus less volatile material present and more char (12).

In gasification there are four standard reactor designs: 1) Countercurrent design, 2) Cocurrent design, 3) Fluidized-bed design, and 4) Cocurrent-suspension design (12). The countercurrent design produces maximum heat recovery, low temperatures of exit gases, drying and devolatilization of green fuels, high carbon conversion, and minimal contamination of product gas with solids (12). The cocurrent design uses more heat and produces a product gas stream with a lower heating value and a significantly higher temperature (12). A high yield of gasification occurs when using the fluidized-bed design; however, higher exiting temperature and the carry over of ash into the product stream cause some problems (12). The cocurrent-suspension design suspends the particulate material in the gasifying medium. This requires finely ground and low moisture material and had been designed for use with coal (12).

Zhang and coworkers (13) converted hog manure into an oil similar to conventional crude oil thru a hydro-pyrolysis procedure. Slurry of hog manure and water $\left(10 \%-25 \%\right.$ wt hog manure) were heated to high temperatures $\left(250-350^{\circ} \mathrm{C}\right)$ and pressured to between 6-18.5 MPa in a carbon monoxide enriched atmosphere (13). Under these conditions, an oil product was obtained and the heating value of 32,000$36,700 \mathrm{~kJ} / \mathrm{kg}$ was determined. The oil-like product was found to be similar to a crude oil.

Changing World Technologies (CWT), a New York Environmental Technology Company funded a factory in Carthage, Missouri, that turns the wastes from turkeys into 
clean-burning fuels (14). This conversion is completed using a thermodepolymerization process that uses intensive heat and pressure to break down the waste into natural gas, fuel oil, and minerals (14). A thick slurry of water and ground waste is heated to $260^{\circ} \mathrm{C}$ and $600 \mathrm{psi}$ for $15-60$ minutes (14). The pressure is then dropped and the steam is recaptured to power the process (14).

A unique experiment was done by Molton and coworkers (15) in which sewage was reacted with water near super critical conditions. The purpose of this reaction was to produce a clean water stream from sewage water. Although that goal was reached, it was observed that the solid subsequently produced had a significantly higher heat of combustion value than the dried, untreated sewage materials (15). This indicated that the water at that temperature and pressure reacted with the sewage and enhanced the heat of combustion of the solids. The original work completed at WVU (described in Chapter 3) is an extension of that work with the goal of producing an extender for fuel oil from the products of such a hydro-pyrolysis process.

\subsection{ENERGY ISSUES}

The energy source of first-world nations is primarily petroleum. The United States uses 20 million barrels of petroleum per year, of which $58 \%$ is imported (16). Europe uses 14 million barrels of petroleum a year, of which $51 \%$ is imported (17). Japan uses 5.4 million barrels of petroleum per year, of which $98 \%$ is imported (17). The costs of defending oil supplies (such as the Persian Gulf) are estimated to be $\$ 10$ 23 billion dollars per year (18). Additional costs are also present in maintaining our strategic petroleum reserve, which in 2001 consisted of approximately 590 million 
barrels of oil. The cost of maintaining this reserve is high, more than $\$ 200$ million per year (18).

As the world's energy supply of petroleum diminishes, effort has been expended on researching new energy sources. There have been many advances in nuclear energy production. In fact, the $77 \%$ of the electricity in France is supplied by nuclear power (19). This is a significant change from 1973 when $80 \%$ of France's electricity came from fossil fuels (19). More emphasis is being given to solar and wind energy. Wind energy currently contributes approximately 100 trillion BTU (16) per year to the United States energy needs. Locations suitable for wind power are limited, but the industry continues to grow. This is supported by the environmental concerns, since both wind and solar energies are considered "green" energies.

\subsection{BIOFuel TECHNOLOgY}

A considerable effort has been given to renewable biofuels. The main type of biofuel is biodiesel fuel. Biodiesel currently requires a subsidy to compete directly with petroleum-based fuels. Incentives from the federal and state governments are encouraging rapid growth in the biodiesel industry (20). The price of B20 (20\% blend of biodiesel fuel) was $\$ 1.72$ per gallon in the fall of 2004 compared to $\$ 1.53$ per gallon for No. 2 diesel fuel; however, tax credits and other incentives could decrease this differential (21). Current production levels are 20-25 million gallons per year in the United States and 500 million - 1 billion in Europe (20). Germany alone produces 185 million gallons of biodiesel annually (21). The largest European production plant is located in France has an annual production capacity of 70 million gallons per year (21). 


\subsection{OIL-BASEd Biodiesel Fuel}

Biodiesel fuel contains monoalkyl esters, which are formed by catalyzed reaction of triglycerides in the oil and animal fat with a monohydric alcohol (20). The most common feed stock is vegetable oil; however, it contains glycerin as well. Several different feed stocks, either singularly or in combination, are used to make biodiesel fuel. Animal fats and used cooking oil are used in the biodiesel process; however, the used cooking oil requires further processing to remove the foreign particles (21). Coconut, rape seed (canola), sunflower, mustard, and soybean are a few of the crops that are made into biodiesel fuel, with canola giving the highest oil yield (21). The major biodiesel producing region, Europe, uses canola, and worldwide, it makes up $84 \%$ of the feedstock material used, followed by sunflower at $13 \%(21)$. The United States uses mostly soybean in its production of biodiesel fuel (21).

The first step in making biodiesel is to separate the glycerin from the oils by using a catalyst and alcohol (21). The catalyst is usually a strong base such as sodium or potassium hydroxide (20). This process is called transesterification, where a triglyceride and methanol react in the presence of a catalyst to form a mixture of fatty ester and glycerin. Most of the processes for the production of alkyls esters for fuel were developed in the 1940 s and are described by a series of patents by E.I. DuPont and Colgate-Palmolive-Peet (20). There original objective was to develop a method to extract glycerol for soap production (20). Glycerol could easily be separated from the esters due to its high insolubly and would be readily removed by centrifugation. They determined that other alcohols besides methanol could be used; however, it may be 
difficult to remove later due to the azeotroph formed with the higher alcohols and water (20). Water and free fatty acids present in the feed stock would inhibit the reaction, but the free fatty acids could be converted to alkyl esters with an acid catalyst (20).

A parametric study of the transesterification reaction with variables temperature, molar ratio of alcohol to oil, type of catalyst, and the degree of refinement of the oil was completed by Freedman et al (22). They observed that the reaction proceeded to completion in 1 hour at $60^{\circ} \mathrm{C}$, but took 4 hours at $32^{\circ} \mathrm{C}$. They also found that mono- and di-glycerides of saturated fatty acids will easily crystallize from the biodiesel fuel and caused engine problems (22).

In most commercial production of biodiesel fuel, alcohol, catalyst, and oil are combined in a reactor and agitated for 1 hour at $60^{\circ} \mathrm{C}$. Batch reactors are used in smaller plants; however, continuous stirred tank reactors (CSTRs) are used in large facilities (more than 4 million liters per year) (20). Below is a diagram of the processes involved in biodiesel production. 


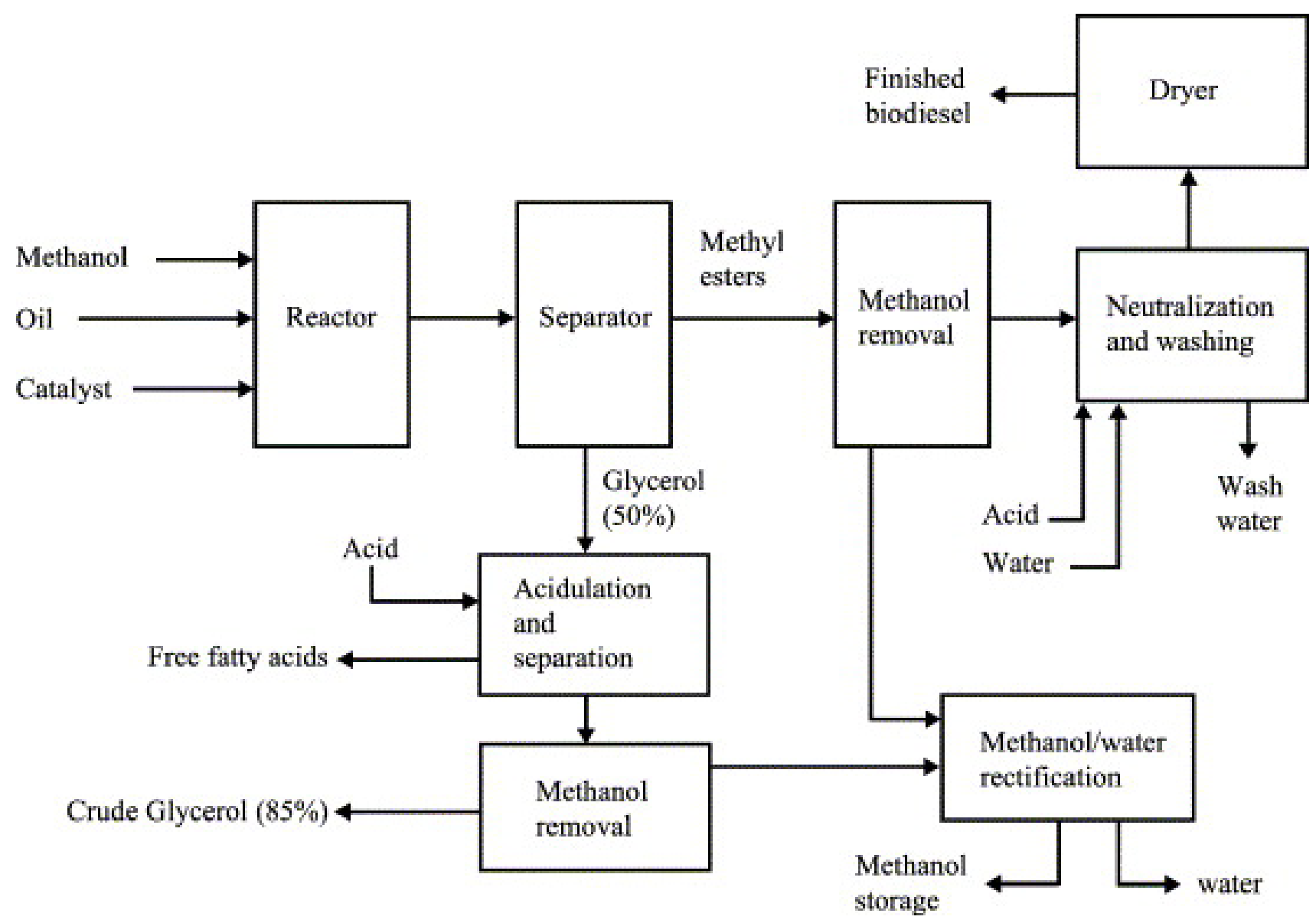

Figure 1: Process Flow Schematic for Biodiesel Production (20)

Following the reaction, the glycerol is separated from the methyl ester. This glycerol stream is approximately $50 \%$ glycerol, and the remainder is methanol and most of catalyst and soap. The excess methanol tends to act as a solubilizer and can slow the separation (20). Water can be added to the mixture following reaction to improve the glycerol separation (20). To refine the glycerol, acid is added to the stream to split the soap into free fatty acids and salts. If a large amount of free fatty acids are present, they are insoluble in the glycerol and will float to the top where they can be removed and recycled (20). The salts may be soluble or may precipitate out of the glycerol. 
One frequently used option is to use potassium hydroxide as the catalyst and phosphoric acid for neutralization (20). This produces potassium phosphate, a fertilizer.

Following the separation for the glycerol, the methyl esters enter a neutralization step, passing then through a methanol stripper (usually a vacuum flash process or a falling film evaporator) (20). Any soap that may be present in the biodiesel will be split with the addition of acid as in the glycerol refining. The remaining catalyst will also be neutralized by the addition of the alcohols. Next, the water-washing step occurs to remove any of the salts (produced by the acid addition), catalyst, soap, methanol or free glycerol from the biodiesel. The free fatty acids remain in the biodiesel (20). The remaining water is removed by a vacuum flash process. The biodiesel fuel produced must meet ASTM D 6751-02. This standard gives the required extent of the reaction through specifications for the total glycerol remaining in the fuel (20).

The transesterification reaction is limited by the low solubility of the alcohol in the oil. Boocock et al have developed a technique for accelerating the reaction rate by introducing the co-solvent to create one phase $(23,24)$. The main concerns with this method are the extra complexity of separation for the recycling or recovering of the co solvent. Additional concerns about the hazard of the co solvents used, tetrahydrofuran or methyl tertiary butyl ether have been brought forth.

Biodiesel is clearly an environmental improvement over conventional diesel fuel. The exhaust emissions of carbon monoxide, unburned hydrocarbons, and particulate matter are lower in biodiesel fuel; however, a slight increase in nitrogen oxides is observed (20). Two petroleum-based diesel fuels (No. 1 and No. 2 diesel fuel) were compared with a biodiesel from soybean oil and a $20 \%$ blend of the No. 2 diesel fuel with 
the soybean biodiesel (25). The carbon monoxide (CO) emissions were reduced $18.3 \%$ when comparing the No. 2 diesel fuel with the biodiesel and $7.6 \%$ when comparing No. 2 diesel to the $20 \%$ blend (25). The unburned hydrocarbon emission was reduced by 42.5\% comparing the No. 2 diesel fuel to the biodiesel; however, no significant reduction was found comparing the $20 \%$ blend to the No. 2 diesel fuel (25). The nitrogen oxide emission were increase by $11.2 \%$ when comparing the No. 2 diesel fuel to the biodiesel fuel and an increase of $0.6 \%$ was found comparing the No. 2 diesel fuel to the $20 \%$ blend (25). Overall the fuels tested preformed the same except it was found that the biodiesel had a higher fuel consumption reflecting it lower energy content, but significant improvements in the $\mathrm{CO}$ and unburned hydrocarbon emissions were observed (25).

The combined vegetable oil and animal fat production in the United States totals about 35.3 billion pounds per year. This production could provide 4.6 billion gallons of biodiesel. This would only account for $14 \%$ of the diesel fuel demand of on-highway usage. Biodiesel will not be able to replace petroleum based diesel fuel, but it can allow for a decreased dependence on foreign oil.

\subsection{Ethanol-Based Biodiesel Fuel}

Ethanol is an alcohol produced through the fermentation of plant sugars harvested from agricultural crops and resources (26). The main crop used to produce ethanol is corn. In wet milling, the corn is finely ground and separated into component sugars and then fermented and distilled to make ethanol (26). Only the starch from the corn is used to make ethanol; the remainder is used for animal feed, corn oil, and other 
products (26). In dry milling, the entire corn kernel is fermented and made into ethanol.

Each milling process is shown in Figure 2.

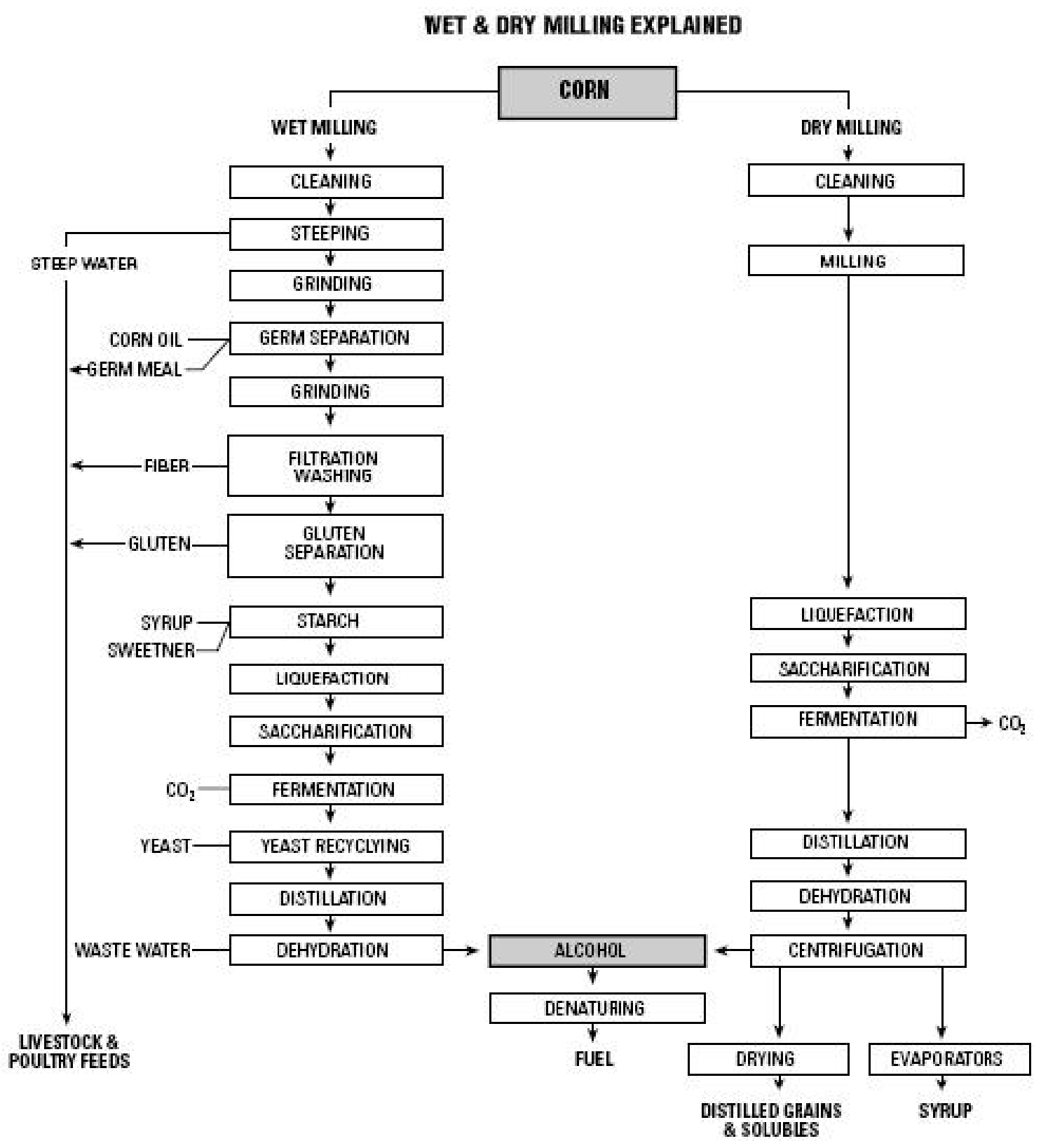

Figure 2: Ethanol Dry and Wet Milling Process Flow Diagram (27) 
The dry-milling process is the most widely used in industry. In the dry-milling process, there are eight main steps (Figure 3 ). The first step is milling where the corn is passed through a hammer mill and ground into a fine powder (27). Next, the powder is mixed with water and alpha-amylase, and then passed through cookers where the starch is liquefied using heat (27). Cookers with both a high-temperature stage (120$\left.150^{\circ} \mathrm{C}\right)$ and a lower temperature holding period $\left(95^{\circ} \mathrm{C}\right)$ are used $(27)$. The high temperatures reduce bacteria levels in the mash(27). The mash from the cookers is cooled, and the secondary enzyme (gluco-amylase) is added to convert the liquefied starch to fermentable sugars (dextrose) (27). The yeast is added next and allowed to ferment. In a continuous process, the fermenting mash is allowed to flow through several fermenters until it is fully fermented and leaves the final tank. In a batch process, the mash stays in one fermenter for about 48 hours before the distillation process is started (27). The fermented mash, beer, contains about $10 \%$ alcohol plus all the non-fermentable solids from the corn and yeast cells. The mash is then pumped into a continuous flow, multi-column distillation system (27). The alcohol leaves the top of the final column at about $96 \%$ strength, and the residue mash, stillage, is transferred from the base of the column to the co-product processing area (27). The alcohol from the top of the column passes through a dehydration system, molecular sieve, where the remaining water will be removed (27). The ethanol that will be used for fuel must be denatured, or made unfit for human consumption, with a small amount of gasoline (2$5 \%)$. There are two main co-products created in the production of ethanol: distillers grain and carbon dioxide (27). Distillers grain, used wet or dry, is a highly nutritious 
livestock feed. Carbon dioxide is given off in great quantities during fermentation, and many ethanol plants collect, compress, and sell it for use in other industries (27).

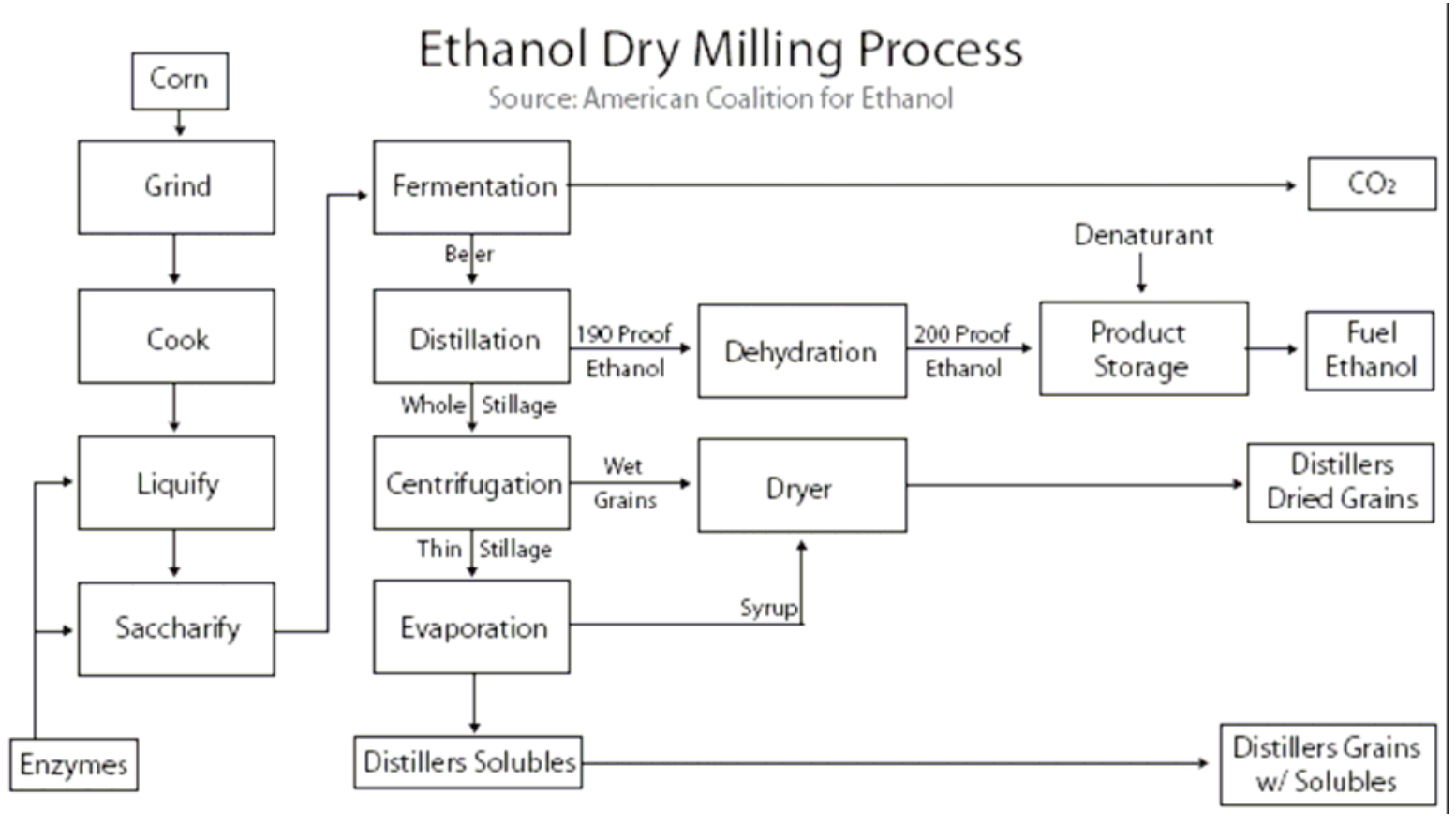

Figure 3: Dry-Milling Process Flow Diagram (27)

The wet-milling operation is more elaborate because the grain must be separated into its components (Figure 4). After milling, the corn is heated in a solution of water and sulfur dioxide for 24 to 48 hours to loosen the germ and the hull fiber (27). The germ is then removed from the kernel, and corn oil is extracted from the germ (27). The remaining germ meal is added to the hulls and fiber to form corn gluten feed. A highprotein portion of the kernel called gluten is separated and becomes corn gluten meal, which is used for animal feed (27). In wet milling, only the starch is fermented, unlike dry milling, where the entire mash is fermented (27). 


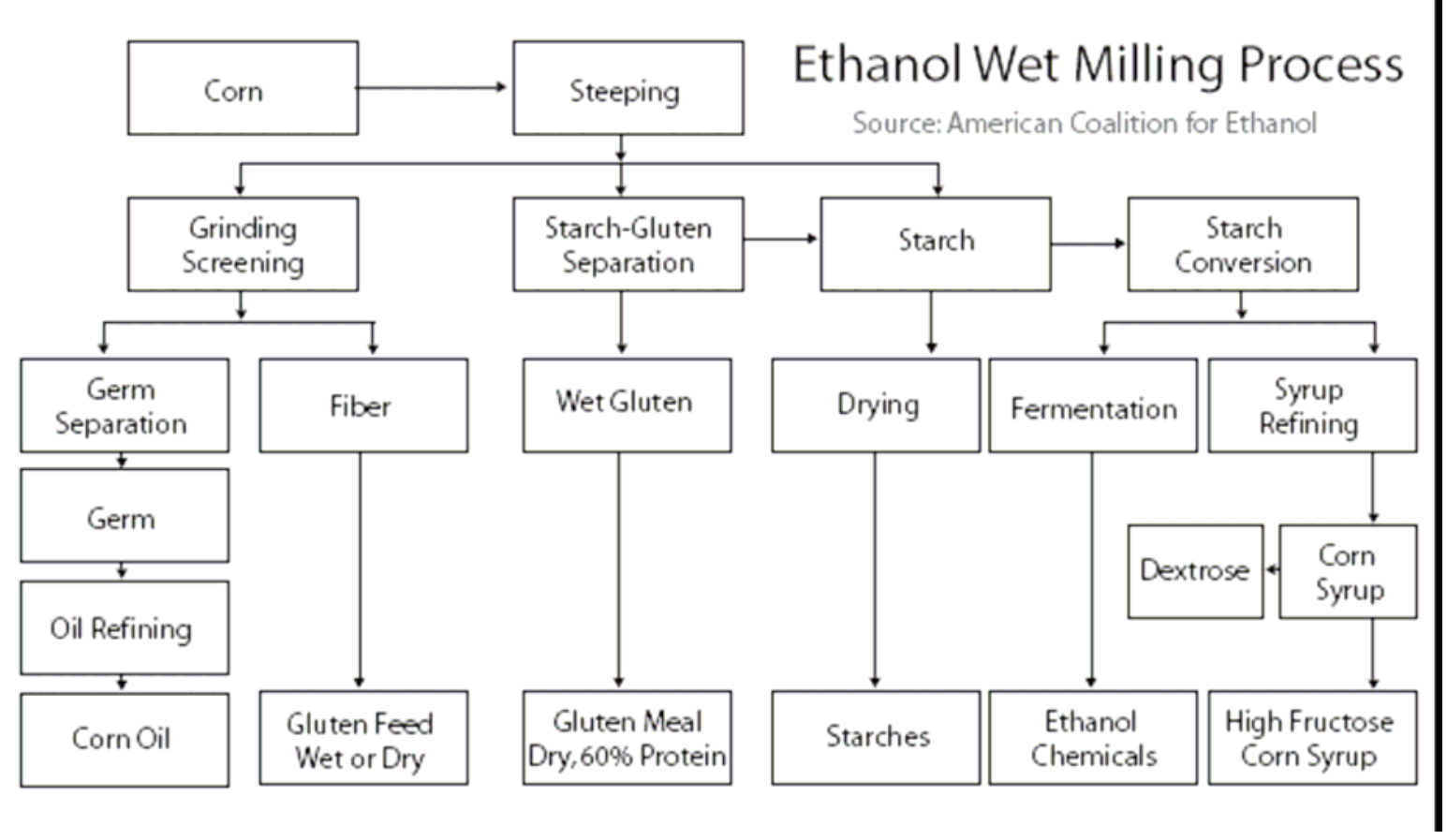

Figure 4: Wet-Milling Process Flow Sheet (27)

Ethanol has been used since the mid 1980's; however, in 2000, it reached its alltime production level of 1.63 billion gallons (28). This increase in production was brought about by the lowering price of corn (levels comparable to the depression, factoring in inflation) and the interest in environmentally clean fuels (26). The awareness of ethanol as an alternative fuel was led by the Alternative Fueled Vehicle (AFV) mandate in the Energy Policy Act (EPAct) of 1992 (26). This mandate required that government and utility/fuel provider fleets purchase AFVs with natural gas, propane, methanol, and ethanol qualifying as alternative fuels (26).

There are two main types of commercial ethanol based fuels: Ethanol 10 (E10/Gasohol) and Ethanol $85(E-85)(26)$. E-10 is blend of 10 percent ethanol and 90 percent gasoline. When the blending of fuels first began, there were no regulations, and many of incidents of mis-blending occurred (26). Because of the mis-blending, several car manufactures began voiding warranties on their vehicles if ethanol or 
methanol blended fuels were used in them (26). This lead to a distrust in the ethanolblended gasoline; however, ethanol overcame the initial problems, and currently, all car manufacturers now approve the use of ethanol blends of $10 \%$ or less (26).

E-85 fuel, which is 85 percent ethanol, does not run in normal car engines. These vehicles have special hoses, valves, fuel lines, and fuel tanks that resist alcohol corrosion (26). They are also equipped with a fuel sensor that detects the amount of ethanol in the fuel tank and a larger tank to compensate for the mileage decrease (26). Currently, there are few E-85 refueling stations due to the high cost of installation of an E-85 underground tank, $\$ 52,000$ (26). The return on investment is questionable with an unpredictable market (26).

There is also an ethanol/diesel fuel blend called E-diesel. The blend can range from $7.7 \%$ to $15 \%$ ethanol and $1 \%$ to $5 \%$ special additives to prevent separation at low temperatures or if water contamination occurs (26). The E-diesel has the same disadvantages that the gasoline blends have, such as decreased gas mileage and increased cost.

\section{ORGINIAL INVESTIGATION}

\subsection{PRELIMINARY EXPERIMENTS}

In the original research, there were three steps in the experimental procedure. The first step evaluated the concept of converting hog manure to a fuel using small, bench-top tubing reactors. The second phase involved investigating the reaction in a 
larger, one-gallon, stirred, autoclave reactor. The third step involved blending the products of the one-gallon reactor with diesel fuel and tests the blends for fuel potential. 3.2 Step one: Evaluation of Conversion Potential Using Tubing Bomb EXPeRiments The tubing-bomb reactors were made from 6-inch lengths of 1 inch ID 316 stainless steel tubing with a 0.25 -inch wall thickness. The lengths were capped at each end with swagelock end caps. A 10 -inch length of 0.25 -inch 316 stainless steel tubing was inserted into a swagelock coupling in one end of the caps. At the end of that tubing was fixed a 101FFS 6000-psi valve. The small tube was used to support the reactor, and the valve was used to release the gases produced after the reaction. The hog manure was dried and ground to achieve a consistent blend for experiments. The reactor was then immersed in a fluidized sand bath, heated to $360^{\circ} \mathrm{C}$, and allowed to react for 2 hours. The reactor was then removed and placed in cold water to stop the reaction. The tubing-bomb reactors initially contained 18.0 grams of dried hog manure mixed with 49.0 grams of water. The reaction products were removed and weighed to evaluate mass closure. The heating values of the products were determined, and a sample of the gas produced was collected for chemical analysis.

\subsection{RESULTS: TUBING BOMB EXPERIMENTS}

The products of the reaction were three states: a gas that is $96 \%$ carbon dioxide, an aqueous phase, and a sticky tar like solid (Table 1). Following the reaction, the tubing reactor was weighed. The gas was then vented and the reactor weighed again. The reactor was then opened and contents removed. The liquid and solid portions were mixed with diesel fuel and heated to $70^{\circ} \mathrm{C}$ with continuous stirring. The hot mixture was 
then filtered to remove any insoluble solids. The filtrate was put into a separation flask and the aqueous phase was removed.

Table 1: Results from tubing bomb experiments

\begin{tabular}{|l|c|c|}
\hline & Experiment 1 & Experiment 2 \\
\hline Temperature ( $\left.{ }^{\circ} \mathbf{C}\right)$ & 350 & 370 \\
\hline Time (hr) & 2 & 2 \\
\hline Weight in grams & & \\
\hline Hog Manure & 18.04 & 18.04 \\
\hline Water & 48.35 & 49.17 \\
\hline & & \\
\hline Gas & 2.69 & 3.37 \\
\hline Reactor Contents & 63.7 & 63.84 \\
\hline Aqueous Solution & 36.64 & 42.29 \\
\hline Solids & 27.06 & 21.45 \\
\hline Mass Balance & 66.39 & 67.21 \\
\hline Percent & & \\
\hline Gas & $4.04 \%$ & $5.02 \%$ \\
\hline Aqueous & $55.18 \%$ & $63.01 \%$ \\
\hline Solids & $40.78 \%$ & $31.96 \%$ \\
\hline
\end{tabular}

\subsection{Step two: Scale Up Using ONe-Gallon AutoclaVe EXPeRIMENTS}

In the second phase of the experiments, larger quantities of hog manure were reacted in a 1-gallon reaction vessel. The reactor was built by Pressure Products Industries, Inc. (Warminster, PA) and is an IC Series model number 94U-00058. It was used without any alterations. The autoclave was equipped with a heating jacket capable of reaching temperatures in excess of $500^{\circ} \mathrm{C}$ and a pressure of $6000 \mathrm{psig}$. The reactor was equipped with a variable speed magnetic stirrer with speed set to $85 \mathrm{rpm}$. About 600 grams of ground hog manure was mixed with 600 grams of distilled water. After the reactants were put into the reactor, it was sealed and its contents were heated at $3^{\circ} \mathrm{C}$ per minute until a final temperature of $360^{\circ} \mathrm{C}$ was reached. The heating system 
was then turned off, and the vessel was allowed to cool to room temperature. After the reactor was cooled to room temperature, the reactor pressure was observed to be about 200 psig. This pressure represents the gas produced as in the tubing bombs. The gas was permitted to escape through a valve into a gas collection bag for chemical analysis. The reactor was opened and its contents were removed. The solids were separated from the aqueous phase by filtration. Solids were washed with heated diesel fuel in a large roto-vap reactor at $70^{\circ} \mathrm{C}$ in a nitrogen atmosphere. The mixture was filtered to separate the insoluble solids from the diesel fuel solution.

\subsection{RESULtS: ONE GALLON REACTOR EXPERIMENTS}

The hot diesel fuel dissolved appreciable quantities of reacted agricultural waste; however, when the diesel fuel cooled, significant precipitation of solids was seen. Room temperature diesel fuel contained only $11 \%$ processed hog manure.

\subsection{Step three: Preparation and Evaluation of Processed Extended Diesel Fuel}

It was desirable to increase the amount of hog manure product in the diesel fuel. The mechanics by which this was accomplished involved first obtaining large quantities of the product from the hog manure-water reaction in the gallon reactor. After sufficient quantities of the sample were prepared, the aqueous solution was decanted off the tarry residue. Diesel fuel was added to the tarry residue and the mixture was emulsified. A surfactant, lecithin, was added to stabilize the emulsion. The blend was diluted to $75 \%$ diesel fuel, $20 \%$ processed hog manure, and $5 \%$ lecithin. The emulsified blend was then agitated vigorously, and then sprayed through a small nozzle with an orifice size 
0.0005 inch to form an aerosol. The pressure at the nozzle orifice was $8000 \mathrm{psig}$. The droplets of aerosol were condensed. The tar globules in the condensate were further reduced in size by pressurizing the emulsion though a smaller orifice nozzle. Finally, the emulsion was again pressurized and passed through a standard fuel injector, commonly used in diesel engines. Between each spraying the blend was passed through a 0.0036 -inch mesh filter on the nozzles to remove any non-emulsified material. The final blended mixture was observed to be stable for 6 months, eventually precipitating after 12 months of storage. It was felt that this blend could be used for a test run in a diesel engine. An Onan diesel engine has performed successfully using this fuel for 60 hours. Samples of this fuel were analyzed for fuel suitability as described in Appendix A.

\subsection{RESULTS OF FUEL ANALYSIS}

From Table 2, it may be noted that many of the properties of diesel fuel are the same as the blended hog manure fuel. Several items do standout as different: viscosity, ash, and sulfur. The viscosity of the blended fuel was (implies statistics were performed) substantially higher; however, due to the successful performance of the engine, this is thought not to be an issue. It may also be noted that the sulfur content was reduced from normal diesel fuel, showing that the blended fuel has less sulfur pollution potential. The ash in the blended fuel is substantially higher and will have to be addressed. This increased ash concentration will more rapidly plug the fuel line filter and/or degrade a diesel engine's injector system and perhaps erode some of the piston rings and valves. Examination of the Onan engine's injector nozzle after operating for 
60 hours using the extended diesel fuel showed some evidence of erosion, presumably due to the ash content in the emulsion.

Table 2: ASTM Test Results for Original Diesel Fuel Extender

\begin{tabular}{|c|c|c|c|c|c|}
\hline \multirow[t]{2}{*}{ Specification } & \multicolumn{2}{|c|}{ General Literature } & \multicolumn{3}{|c|}{ Laboratory Results } \\
\hline & ASTM & \#2 Diesel & ASTM & \#2 Diesel & Blended \\
\hline API Gravity & $\mathrm{D}-287$ & 39 & $\begin{array}{c}\text { Fls } \\
\text { calculated }\end{array}$ & $\begin{array}{c}\rho=0.8506 \\
A P I=34.85\end{array}$ & $\begin{array}{c}\rho=0.8634 \\
A P I=32\end{array}$ \\
\hline Flash Point & D-93 & $125^{\circ} \mathrm{F} \min$ & D-93 & $155^{\circ} \mathrm{F}$ & $159^{\circ} \mathrm{F}$ \\
\hline $\begin{array}{l}\text { Water \& } \\
\text { Sediment }\end{array}$ & D-1796 & $\begin{array}{c}0.05 \mathrm{vol} \% \\
\max \end{array}$ & D-2709 & $0 \mathrm{vol} \%$ & $5 \mathrm{vol} \%$ \\
\hline $\begin{array}{c}\text { Viscosity @ } \\
40^{\circ} \mathrm{C}\end{array}$ & D-445 & $1.9 \geq 4.1 \mathrm{cSt}$ & D-445 & $2.583 \mathrm{cSt}$ & $\begin{array}{c}11.241 \\
\mathrm{cSt}\end{array}$ \\
\hline Ash & $\mathrm{D}-482$ & $0.01 \% \max$ & $\mathrm{D}-482$ & $0.000 \%$ & $4.702 \%$ \\
\hline Sulfur & D-2622 & $\begin{array}{c}0.5 \text { mass } \% \\
\max \end{array}$ & D-2622 & 0.1349 & 0.0516 \\
\hline $\begin{array}{l}\text { Copper } \\
\text { Corrosion }\end{array}$ & $D-130$ & No. 3 max & $D-130$ & $1 \mathrm{~A}$ & $1 \mathrm{~A}$ \\
\hline $\begin{array}{l}\text { Cetane } \\
\text { Number }\end{array}$ & D-613 & $40 \mathrm{~min}$ & D-613 & 45.9 & 45.4 \\
\hline
\end{tabular}

\subsection{CONCLUSIONS OF PASt RESEARCH}

The research of Batelle laboratory (13) showed that the solids in sewage reacted with water at near supercritical conditions. The results of this research support this observation. The composition of the gases generated from our experiments was shown to be nearly $95 \%$ carbon dioxide. The aqueous phase contained only about $50 \%$ water. The remainder was a mixture of small chain organic acids and alcohols. The aqueous phase has a heat of combustion of $1057 \mathrm{BTU} / \mathrm{lb}$. The solids produced have a tarry 
consistency and is easily separated from the liquid phase. When the solid is dried it is shown to have a heat of combustion of $11,894 \mathrm{BTU} / \mathrm{lb}$. When compared to dried hog manure with its BTU/lb value of 7051 , it is obvious that the reaction with water converted the solid hog materials to a material comparable to coal and only slightly lower than diesel fuel.

The solids after reaction are homogenous, interact with the surfactant lecithin, and can easily be emulsified into diesel fuel. Emulsions were seen to be stable for at least a period of two months. Blends of $75 \%$ diesel fuel, $20 \%$ tarry solids from processed hog manure, and $5 \%$ lecithin were emulsified and used to run a diesel engine without any alteration to the diesel engine.

The emulsions were evaluated by several ASTM protocols for diesel fuel. Overall, the emulsions compared favorably with \#2 diesel fuel. The sulfur content was seen to be substantially less than diesel fuel. The cetane number for the emulsion was shown to be very comparable to diesel fuel; however, the viscosity was higher. One of the major concerns with these emulsified blends is the ash content, as they were too high for diesel fuel used in engines. Despite this, an Onan diesel engine was run on the fuel for over 60 hours. Examination of the fuel injector nozzle showed some erosion, probably due to the ash. 


\section{INVESTIGATION}

\subsection{INTRODUCTION}

The present research is an extension of the previous work completed at West Virginia University. The main objective of this research is to eliminate the ash and improve the yield of agricultural waste dissolved in the diesel fuel.

\subsection{EXPERIMENTATION}

There are some experimental difficulties with both the direct reaction of water and dried hog manure and the quality of the extended diesel fuel produced by this approach. This reactant blend was described as having a consistency of thick "cookie dough." In the reactor, this blend was not fluid enough to be stirred to a well-mixed state. Therefore, the heat flow and subsequent reaction dynamics were not uniform within the reactor. The converted hog manure had low solubility in the diesel fuel. The fuel product from this reaction was a blend of emulsified solid in diesel fuel. The ash material in the original hog manure is entrained in the solids. By emulsifying the solids in diesel fuel the resulting product had too high an ash content and too high a viscosity to be useful. The desired product of the reaction is an ashless solution of converted hog manure dissolved in diesel fuel rather than an emulsion that might not have a long shelf life. The vaporization conditions of the desired product fuel should be as nearly identical as diesel fuel so any alterations to an engine using this fuel would be minimal. The present research studies a procedure that potentially solves these challenges.

\subsection{PRESENT ReseARCH}

There are three goals of the present research: 
(1) Increasing the reactant fluidity and de-ashing the product, thereby ensuring more uniform reaction conditions. In order to ensure fluidity of the hog manure/water mixture during reaction, diesel fuel was added. The mixture would have a reduced viscosity. Thus the mixture would facilitate uniformity in heat flow and reaction dynamics. Since the reaction temperature is above the supercritical fluid state of many of the components in the diesel fuel, those components would facilitate the dispersion of the solids and free the entrained ash. The freed ash could then be separated and an ash free product would be produced.

(2) Increasing the soluble components on diesel fuel. Since the hydrolysis products of hog manure are primarily organic acids, which are soluble in water, it was felt that by addition of alcohols, esters might be produced, which are less polar than acids and thus more soluble in diesel fuel. This would increase the total solubility of converted animal waste in diesel fuel.

(3) Evaluating the evaporation conditions of the extended diesel fuel. It would be ideal if the vaporization of the extended diesel fuel matched that of diesel fuel so the alteration to an engine using this fuel would be minimal. Solutions of converted animal waste in diesel fuel would be expected to match much more closely the distillation curves of pure diesel fuel than emulsions. Therefore the addition of alcohols should make a much better product. This will be evaluated using simulated distillation a Varian CP-3800 gas chromatograph . 


\subsection{Diesel Fuel Addition}

One of the major causes for concern in the previous work was the viscosity of the reactant mixture. It was very thick and difficult to pump or easy to handle. In order to decrease the viscosity of the blend, diesel fuel was added to the mixture prior to the reaction. The diesel fuel acted as lubricant and made the mixture very fluid. It was also hypothesized that at the reaction temperature and pressure, some components of the diesel fuel would become supercritical. When they became supercritical, this would allow them to permeate the solid and release the entrained ash material. Two types of reactions were run: (A) dried hog manure with pure water and diesel fuel added (B) dried hog manure with solutions of various alcohols and water and diesel fuel added.

The conversion of hog manure and water in the presence of diesel fuel were investigated using a 1-gallon reaction vessel. The reactor is built by Pressure Products Industries, Inc., and is an IC Series model number $94 \mathrm{U}-00058$. It was used as is without any alterations. The autoclave is equipped with a heating jacket capable of reaching temperatures in excess of $500^{\circ} \mathrm{C}$ and pressures of 6000 psig. The reactor is equipped with a variable-speed magnetic stirrer whose speed was set to $85 \mathrm{rpm}$. The reactants of each experiment were about 500 grams of ground hog manure mixed with 500 grams of distilled water or mixtures of 300 grams water and 200 grams of various alcohols. Sufficient diesel fuel was added to insure fluidity of the entire mixture. This usually was about 600-700 grams of diesel fuel.

After the reactants were put into the reactor, it was sealed and its contents were heated at $3^{\circ} \mathrm{C}$ per minute until a final temperature of $360^{\circ} \mathrm{C}$ was reached. The heating 
system was then turned off and the vessel was allowed to cool to room temperature.

The reactor usually takes approximately 3 hours to heat up and is allowed to cool overnight. After the reactor was cooled to room temperature, the reactor pressure was observed to be about 200 psig. This pressure represents the gas produced in the reaction. The gas was permitted to escape through a valve into a gas collection bag. The reactor was opened and its contents were then removed. The products were then analyzed following the general flow diagram shown in Figure 5.

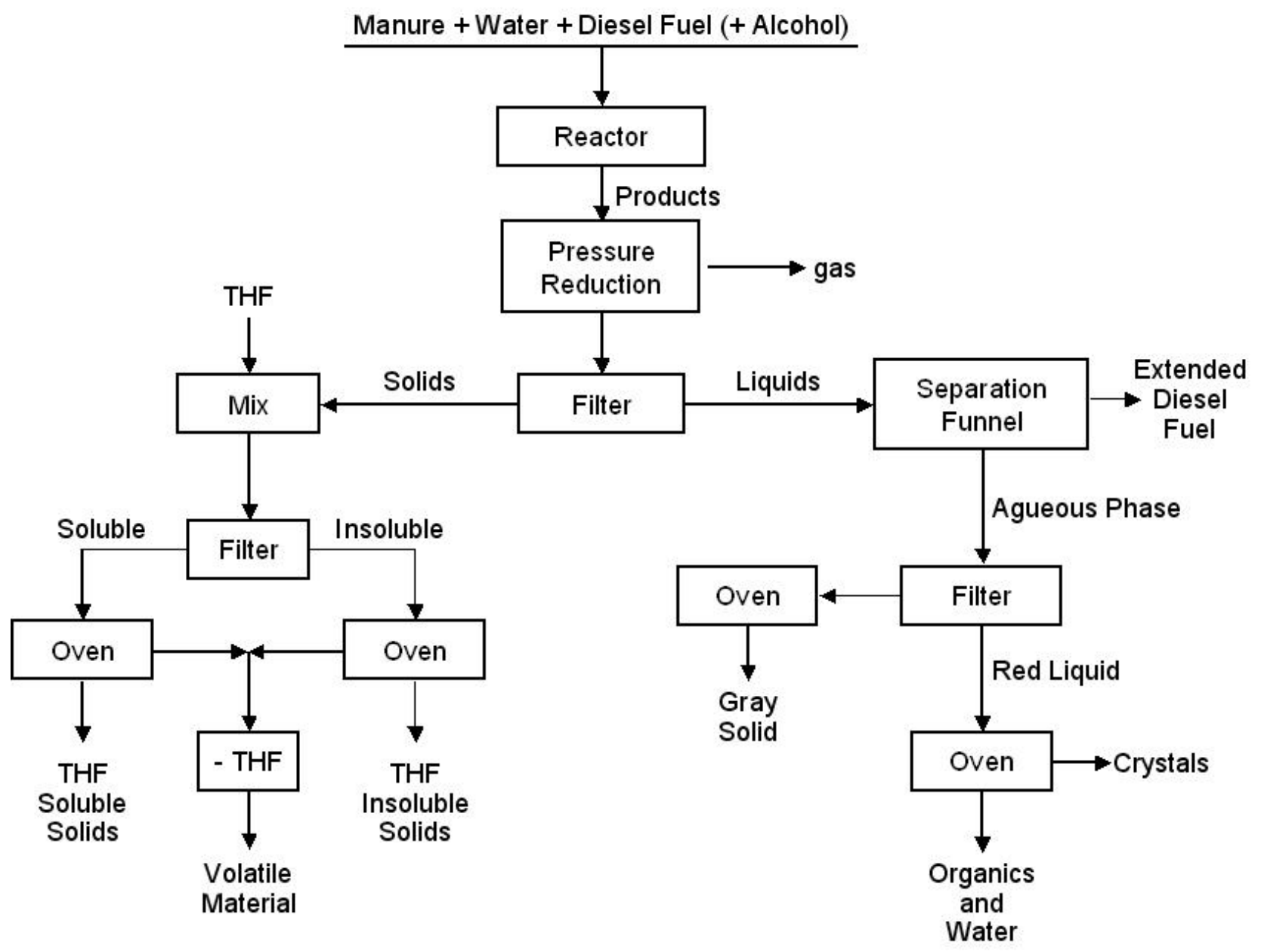

Figure 5: Separation Diagram 
The solids were separated from the aqueous phase by filtration using a screen of 500 $\mu \mathrm{m}$ mesh. The solid phase is a thick tar like material that has cohesive properties and made the filtration very easy. Their weights were recorded for mass balance (Table 3). Two paths of analysis are then followed: one for the liquid phase and a second for the solids.

Table 3: Overall Mass Balance for Diesel Fuel Extender

$\begin{array}{lrc}\text { Reactants } & & \\ \text { Hog Manure } & 500 & \mathrm{~g} \\ \text { Distilled Water } & 500 & \mathrm{~g} \\ \text { Diesel Fuel } & 736 & \mathrm{~g} \\ \text { Total } & 1736 & \mathrm{~g} \\ & & \\ \text { Products } & & \\ \text { Gas Phase } & 155 & \mathrm{~g} \\ \text { Liquid Phase } & 1408 & \mathrm{~g} \\ \text { Solid Phase } & 173 & \mathrm{~g} \\ \text { Total } & 1736 & \mathrm{~g} \\ & & \\ \text { Liquid Separation } & & \\ \text { Extended Diesel Fuel } & 772 & \mathrm{~g} \\ \quad \text { Original Diesel Fuel } & 736 & \mathrm{~g} \\ \quad \text { Diesel Fuel Extender } & 36 & \mathrm{~g} \\ \text { Aqueous Phase } & 636 & \mathrm{~g} \\ \quad \text { Gray Solid } & 65 & \mathrm{~g} \\ \quad \text { Crystals } & 11 & \mathrm{~g} \\ \quad \text { Water and Volatile } & & \\ \text { Organics } & 560 & \mathrm{~g} \\ \quad & & \\ \text { Solid Separation } & 42 \mathrm{~g} \\ \text { THF Soluble } & 69 & \mathrm{~g} \\ \text { THF Insoluble } & 62 \mathrm{~g} \\ \text { Volatile Material } & \end{array}$


In path one, the liquid, an aqueous phase and a diesel fuel phase, was then placed in a separation funnel to allow gravity separation to occur. Two layers were observed: a less dense, dark black liquid (extended diesel fuel), and a more dense, red clear liquid with a gray solid suspended in it. The red liquid, called the aqueous phase, with the gray dispersed solid, was decanted and its weight was taken (Table 3). The extended diesel fuel was then removed and weighed (Table 3). Samples of this extended diesel fuel were retained for chemical analysis and fuel testing. The gray solid was then filtered from the red liquid using vacuum filtration and weights of each recorded. One portion of the red liquid was saved for chemical and fuel analysis. A second portion of the red liquid and gray solid was then placed in a $100^{\circ} \mathrm{C}$ oven to dry. The red liquid evaporated and yielded crystals and a small amount of red-tar like material. The crystals were washed free of the red tar using methanol rinses. The dry weights of the gray solid and crystals were recorded for mass balance (Table 3).

In path two, the solids were washed with THF. Part of the solids dissolved in THF; the other remained insoluble. These were separated by filtration. The weight of the solids and THF solution were recorded. The solids and THF solution were then placed into a $100^{\circ} \mathrm{C}$ oven to dry. Their dry weights were record for mass balance (Table 3). Samples of these materials were retained for chemical and fuel testing.

A sample of the extended diesel fuel, THF insoluble, and the gray solid were taken, and thermogavametric analysis (TGA) and elemental analysis were performed. The TGA results (Table 4) showed that the extended diesel fuel contained no ash; the gray solid material was almost completely ash; and the THF insoluble material contained some ash. The disappearance of the ash from the extended diesel fuel 
validated our theory that the diesel fuel would permeate the solid material in a supercritical state and release the entrained ash material. The gray solid contained most of the ash material present in the form of insoluble phosphate salts.

Table 4: TGA Results on Extended Diesel Fuel, THF Insoluble, and Gray Solid Material

\begin{tabular}{|l|c|c|c|c|}
\hline & Moisture \% & Volatile \% & Ash \% & Fixed Carbon \% \\
\hline Extended Diesel Fuel & 9.63 & 89.67 & 0.00 & 1.20 \\
\hline THF Insoluble & 3.13 & 37.22 & 28.81 & 30.85 \\
\hline Gray Solids & 2.15 & 8.41 & 89.10 & 0.34 \\
\hline Hog Manure & 12.80 & 65.33 & 11.03 & 10.84 \\
\hline
\end{tabular}

The addition of the diesel fuel allowed the reactant mixture to be much more fluid solving one of the initial concerns. Analysis of the resulting products showed that 36 grams of hog manure dissolved into the diesel fuel directly (Table 3) with no ash present (Table 4). The lack of ash solved another of the original problems. The emulsified solid in diesel fuel contained $4 \%$ ash material. All the ash materials were contained in the aqueous phase. The gray solid dispersed in the aqueous phase and the crystals produced when the red liquid phase was evaporated were found to be phosphate salts through Scanning Electron Microscopy (Figure 6) and X-ray Refractive Fluorescence (Figure 7). 


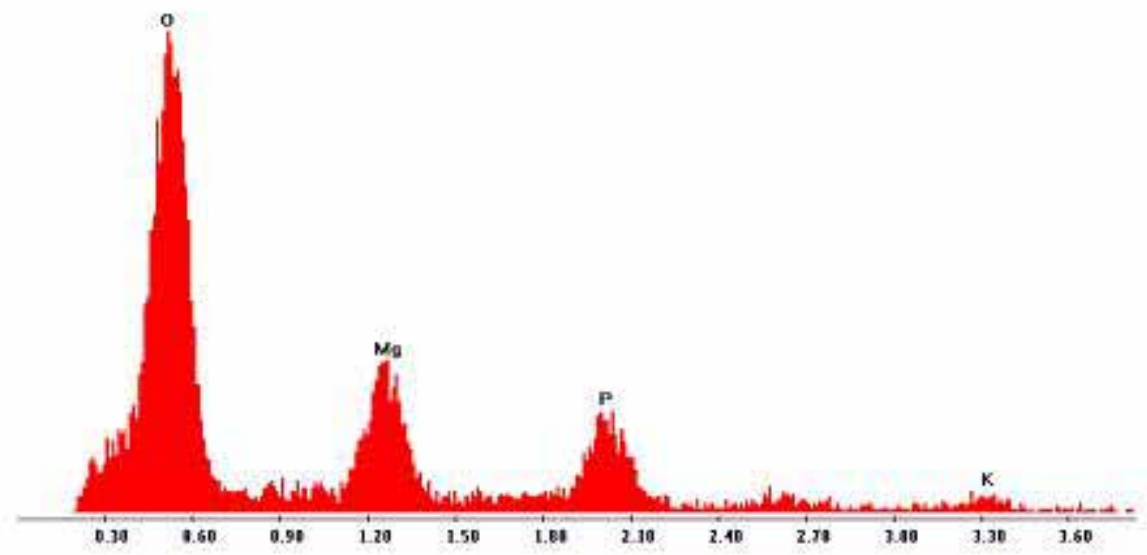

Figure 6: XRF Analysis of Crystal Material

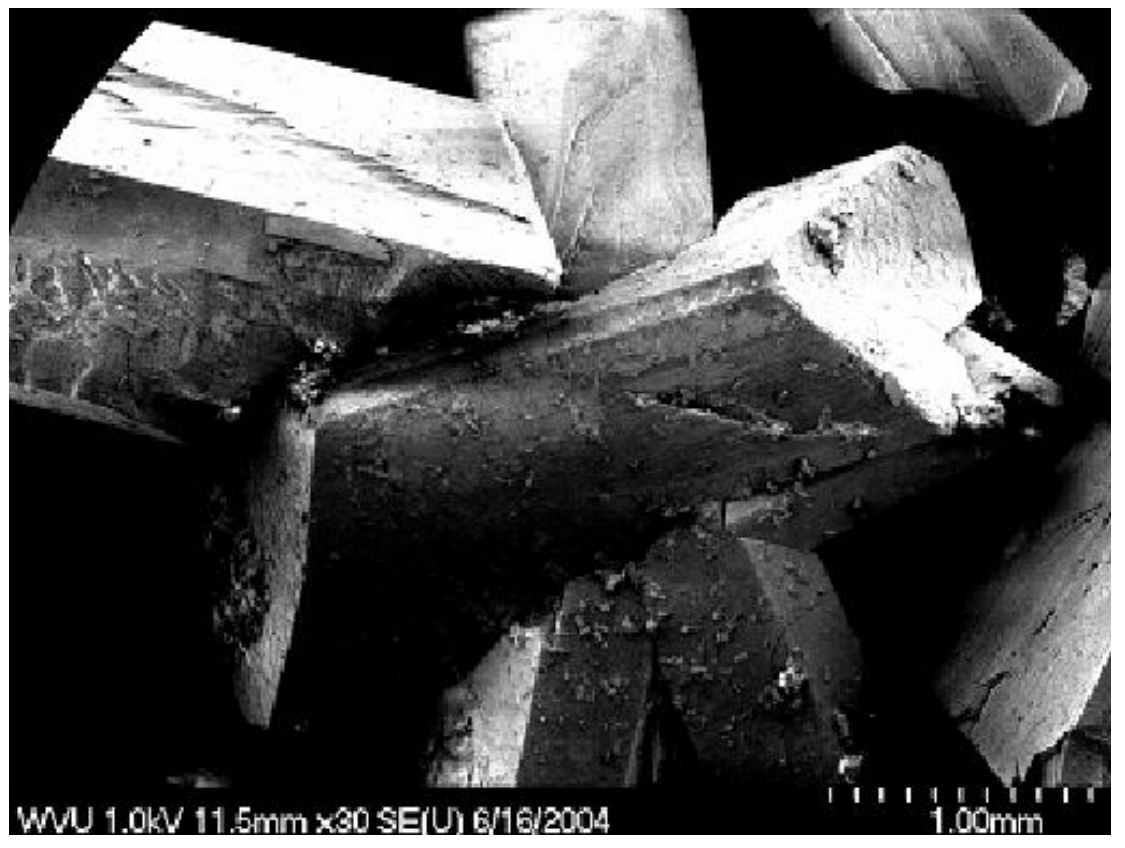

Figure 7: SEM Photograph of Crystal Material 
Chemical analysis (chromatography) of the aqueous phase was also completed and indicated that this phase was $51.5 \%$ water. The remainder of the phase was composed of small chain alcohols and acids. The chromatography was completed on a Varian Star 3400 with a capillary column (CP-WAX 52CB 25m0.53mm2 $\mu \mathrm{m}$ \#CP7658). At first, the unit was calibrated using solutions of known water content. The samples of aqueous phase were then run. An example of the output of the chromatograph is shown in Appendix B.

\subsection{Diesel Fuel Addition With Alcohol Water Solutions}

The quantity of converted hog manure in the above experiment was too low to qualify it as an extended diesel fuel. Through an observation about the sour smell the solid material had, it was hypothesized that there were organic acids present in the solid material. The organic acids would be polar and, therefore, not dissolve in the diesel fuel. If alcohols were added to the water, these acids may react to form esters, which are non-polar and therefore should dissolve in the diesel fuel, increasing the amount of hog manure present in the diesel fuel. The evaluation of alcohols involved the investigation of increasing chain length. About 500 grams of ground hog manure was mixed with 300 grams of distilled water, 200 grams of alcohol and $600-700$ grams of diesel fuel. The same procedure was followed as described above for the reaction and separation. The mass balances of the alcohol solutions are shown in Table 5. Samples of the extended diesel fuel and THF insoluble materials were again analyzed. TGA results showed that again the extended diesel fuel had no ash present and that the THF insoluble material had varying amounts of ash present (TABLE 6). The percent 
water and heating values of the aqueous phase were again tested using the same procedures and equipment listed above. The heating values of the aqueous phases and their percentage of water are shown in Table 7. 
Table 5: Mass Balance for Each Alcohol

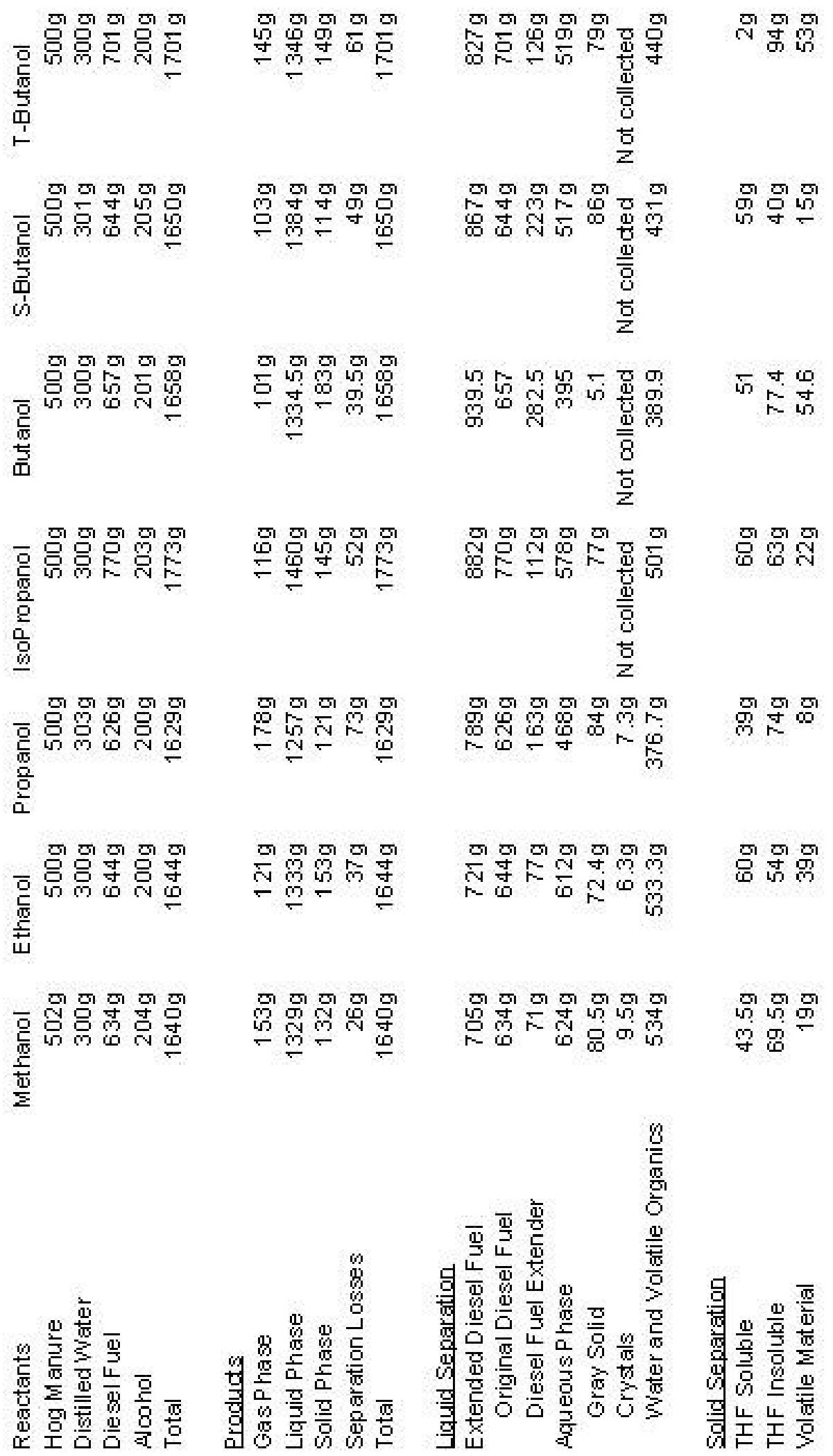


Table 6: TGA Results for Various Alcohol Solutions

Extended Diesel Fuel

\begin{tabular}{|l|c|c|c|c|}
\hline & Moisture \% & Volatile \% & Ash \% & Fixed Carbon \% \\
\hline $\mathrm{HM}, \mathrm{DF}, \mathrm{MeOH}, \mathrm{H}_{2} \mathrm{O}$ & 12.13 & 86.94 & 0.00 & 1.02 \\
\hline $\mathrm{HM}, \mathrm{DF}, \mathrm{EtOH}, \mathrm{H}_{2} \mathrm{O}$ & 15.2 & 83.75 & 0.00 & 1.05 \\
\hline $\mathrm{HM}, \mathrm{DF}, \mathrm{PrOH}, \mathrm{H}_{2} \mathrm{O}$ & 17.87 & 81.06 & 0.00 & 1.08 \\
\hline $\mathrm{HM}, \mathrm{DF}, 2-\mathrm{PrOH}, \mathrm{H}_{2} \mathrm{O}$ & 16.29 & 82.67 & 0.00 & 1.04 \\
\hline $\mathrm{HM}, \mathrm{DF}, \mathrm{BuOH}, \mathrm{H}_{2} \mathrm{O}$ & 31.88 & 65.90 & 0.03 & 2.19 \\
\hline $\mathrm{HM}, \mathrm{DF}, \mathrm{s}-\mathrm{BuOH}, \mathrm{H}_{2} \mathrm{O}$ & 23.29 & 75.90 & 0.01 & 0.81 \\
\hline $\mathrm{HM}, \mathrm{DF}, \mathrm{t}-\mathrm{BuOH}, \mathrm{H}_{2} \mathrm{O}$ & 14.83 & 83.56 & 0.00 & 1.63 \\
\hline
\end{tabular}

THF Insoluble

\begin{tabular}{|l|c|c|c|c|}
\hline & Moisture \% & Volatile \% & Ash \% & Fixed Carbon \% \\
\hline $\mathrm{Hog}$ Manure & 12.80 & 65.33 & 11.03 & 10.84 \\
\hline $\mathrm{HM}, \mathrm{DF}, \mathrm{MeOH}, \mathrm{H}_{2} \mathrm{O}$ & 1.92 & 28.12 & 32.67 & 37.29 \\
\hline $\mathrm{HM}, \mathrm{DF}, \mathrm{EtOH}, \mathrm{H}_{2} \mathrm{O}$ & 0.97 & 30.42 & 23.53 & 45.08 \\
\hline $\mathrm{HM}, \mathrm{DF}, \mathrm{PrOH}, \mathrm{H}_{2} \mathrm{O}$ & 1.86 & 33.85 & 18.65 & 45.65 \\
\hline $\mathrm{HM}, \mathrm{DF}, 2-\mathrm{PrOH}, \mathrm{H}_{2} \mathrm{O}$ & 2.51 & 35.33 & 11.61 & 50.56 \\
\hline $\mathrm{HM}, \mathrm{DF}, \mathrm{BuOH}, \mathrm{H}_{2} \mathrm{O}$ & 3.69 & 40.25 & 3.43 & 52.63 \\
\hline $\mathrm{HM}, \mathrm{DF}, \mathrm{s}-\mathrm{BuOH}, \mathrm{H}_{2} \mathrm{O}$ & 2.77 & 35.46 & 7.36 & 54.41 \\
\hline $\mathrm{HM}, \mathrm{DF}, \mathrm{t}-\mathrm{BuOH}, \mathrm{H}_{2} \mathrm{O}$ & 4.23 & 45.53 & 4.74 & 45.51 \\
\hline
\end{tabular}

Gray Solids

\begin{tabular}{|l|c|c|c|c|}
\hline & Moisture \% & Volatile \% & Ash \% & Fixed Carbon \% \\
\hline $\mathrm{Hog}$ Manure & 12.80 & 65.33 & 11.03 & 10.84 \\
\hline $\mathrm{HM}, \mathrm{DF}, \mathrm{MeOH}, \mathrm{H}_{2} \mathrm{O}$ & 2.97 & 9.28 & 87.40 & 0.36 \\
\hline $\mathrm{HM}, \mathrm{DF}, \mathrm{EtOH}, \mathrm{H}_{2} \mathrm{O}$ & 0.62 & 10.41 & 88.66 & 0.32 \\
\hline $\mathrm{HM}, \mathrm{DF}, \mathrm{PrOH}, \mathrm{H}_{2} \mathrm{O}$ & 2.56 & 23.04 & 63.72 & 10.68 \\
\hline $\mathrm{HM}, \mathrm{DF}, 2-\mathrm{PrOH}, \mathrm{H}_{2} \mathrm{O}$ & 2.57 & 11.46 & 84.39 & 1.58 \\
\hline $\mathrm{HM}, \mathrm{DF}, \mathrm{BuOH}, \mathrm{H}_{2} \mathrm{O}$ & 3.50 & 6.82 & 88.16 & 1.52 \\
\hline $\mathrm{HM}, \mathrm{DF}, \mathrm{s}-\mathrm{BuOH}, \mathrm{H}_{2} \mathrm{O}$ & 2.22 & 7.79 & 89.52 & 0.48 \\
\hline $\mathrm{HM}, \mathrm{DF}, \mathrm{t}-\mathrm{BuOH}, \mathrm{H}_{2} \mathrm{O}$ & 7.41 & 6.31 & 86.20 & 0.08 \\
\hline
\end{tabular}

\subsection{Alcohol Addition Results}

The phases of the products of the reaction were the same of previously mentioned. As shown in Table 5, as the alcohols increased in aliphatic chain complexity, the amount of hog manure dissolved into the diesel fuel increased; however, the solubility of the alcohols must also be taken into account. Methanol, 
ethanol, and propanol favors the water phase, and any unreacted alcohol would enter this phase. Butanol favors the diesel fuel phase, and as such, any unreacted butanol would enter the diesel fuel phase giving a false interpretation of the amount of diesel fuel extender present. As more hog manure was solubilized in the diesel fuel, less solids was produced. The gas production remained nearly constant. Propanol gave the highest amount of extender present in the diesel fuel at 163 grams.

\subsection{Heating Values}

The amount of energy derived from diesel fuel is directly related to the heat of combustion. A bomb calorimeter (PARR 1266) was used to measure the heating values of the fuels and the resulting solids. The heating values of the commercial diesel fuel and the hog manure were first found as a base line for comparison. The extended diesel fuel and THF insoluble material have heating values as shown in Table 7. The heating values of the extended diesel fuels are all close to that of the commercial diesel fuel, although slightly lower.

The THF insoluble material has a significantly higher heating value than that of the original hog manure. The insoluble material may have applications as a fuel as well. This solid material has a heating value similar to coal and could be used to produce the heat required to run the reaction.

The aqueous phase also has a heating value depending on the water content. This could also be used a possible alternative fuel if the water can be removed from the small chain organic alcohols and acids. Several methods should be evaluated such as distillation or reverse osmosis. 
Table 7: Heating Values for the Extended Diesel Fuel, THF Insoluble Solids, and Aqueous Phase

\begin{tabular}{|l|c|c|c|c|}
\hline \multirow{2}{*}{ Reactants } & \multicolumn{4}{|c|}{ BTU/lb Values } \\
\cline { 2 - 5 } & $\begin{array}{c}\text { Liquid } \\
\text { Fuel }\end{array}$ & Black Solid & $\begin{array}{l}\text { Aqueous } \\
\text { Phase }\end{array}$ & $\begin{array}{l}\% \\
\text { Water }\end{array}$ \\
\hline $\mathrm{HM}, \mathrm{DF}, \mathrm{H}_{2} \mathrm{O}$ & 19025 & 11698 & $\mathrm{H}^{\prime} \mathrm{O}$ & 51.5 \\
\hline $\mathrm{HM}, \mathrm{DF}, \mathrm{MeOH}, \mathrm{H}_{2} \mathrm{O}$ & 18268 & 9759 & 1712 & 44.4 \\
\hline $\mathrm{HM}, \mathrm{DF}, \mathrm{EtOH}, \mathrm{H}_{2} \mathrm{O}$ & 18426 & 11950 & 1522 & 42.3 \\
\hline $\mathrm{HM}, \mathrm{DF}, \mathrm{PrOH}, \mathrm{H}_{2} \mathrm{O}$ & 18171 & 10828 & 1815 & 43.5 \\
\hline $\mathrm{HM}, \mathrm{DF}, 2-\mathrm{PrOH}, \mathrm{H}_{2} \mathrm{O}$ & 19090 & 11170 & 3545 & 41.2 \\
\hline $\mathrm{HM}, \mathrm{DF}, \mathrm{BuOH}, \mathrm{H}_{2} \mathrm{O}$ & 17558 & 8343 & 2477 & 50.1 \\
\hline $\mathrm{HM}, \mathrm{DF}, \mathrm{s}-\mathrm{BuOH}, \mathrm{H}_{2} \mathrm{O}$ & 17978 & 12030 & ${ }^{*}$ & 55.0 \\
\hline $\mathrm{HM}, \mathrm{DF}, \mathrm{t}-\mathrm{BuOH}, \mathrm{H}_{2} \mathrm{O}$ & 19377 & 14221 & ${ }^{*}$ & 51.4 \\
\hline \multicolumn{5}{|c}{ Diesel Fuel } \\
Hog Manure & $\mathbf{1 9 3 0 7}$ \\
\hline \multicolumn{5}{|c|}{ H051 } \\
\hline
\end{tabular}

\subsection{SimUlATEd DistilLATION CURVES}

The extended diesel fuel has a heating value similar to diesel fuel. In order to compare the rates of evaporation of the diesel fuel and extended diesel fuel, simulated distillation analysis was completed. This technique measures the amount of material being evaporated as the temperature is increased. Each extended diesel fuel was analyzed producing a boiling point curve. Each of these curves can be found in Appendix C. This curve was then fit to a model. The model used in this case was a sigmoid curve function.

$$
Y=C\left(\ln K-\ln \left(\frac{x}{1-x}\right)\right)
$$

where $\mathrm{K}$ and $\mathrm{C}$ are constants. $\mathrm{X}$ is the percent of the material volatilized and $\mathrm{Y}$ is the boiling point. The model was made linear to facilitate an easier curve fit. The linear model is 


$$
\begin{aligned}
& Y=M x^{\prime}+b \\
& x^{\prime}=\ln \left(\frac{x}{1-x}\right)
\end{aligned}
$$

where $\mathrm{M}$ and $\mathrm{b}$ are new constants. Each of the curve fits can be found in Appendix $\mathrm{D}$. Commercial diesel fuel was also run for a baseline curve and was fit to the model, yielding $M=0.429$ and $b=1.94$ with an $R^{2}$ value of 0.994 . Direct comparisons of the test materials can be made to diesel fuel by comparing the values of $M$ and $b$. The closer $\mathrm{M}$ and $\mathrm{b}$ are to the values for diesel fuel the closer the material is to the evaporation properties of diesel fuel. In Table 8, the constants for each extended diesel fuel are shown.

Table 8: Simulated Distillation Constants for each Extended Diesel Fuel

\begin{tabular}{|c|l|c|c|c|}
\hline \multicolumn{2}{|c|}{ Sample } & M & $B$ & $R^{2}$ \\
\hline & DF & 0.429 & 1.94 & 0.994 \\
\hline $6 / 8 / 2004$ & $\mathrm{HM}, \mathrm{DF}, \mathrm{H}_{2} \mathrm{O}$ & 0.377 & 2.05 & 0.996 \\
\hline $6 / 21 / 2004$ & $\mathrm{HM}, \mathrm{DF}, \mathrm{MeOH}, \mathrm{H}_{2} \mathrm{O}$ & 0.420 & 1.85 & 0.996 \\
\hline $6 / 25 / 2004$ & $\mathrm{HM}, \mathrm{DF}, \mathrm{EtOH}, \mathrm{H}_{2} \mathrm{O}$ & 0.382 & 2.04 & 0.996 \\
\hline $7 / 13 / 2004$ & $\mathrm{HM}, \mathrm{DF}, \mathrm{PrOH}, \mathrm{H}_{2} \mathrm{O}$ & 0.393 & 1.81 & 0.992 \\
\hline $8 / 26 / 2004$ & $\mathrm{HM}, \mathrm{DF}, \mathrm{BuOH}, \mathrm{H}_{2} \mathrm{O}$ & 0.355 & 1.25 & 0.871 \\
\hline $9 / 2 / 2004$ & $\mathrm{HM}, \mathrm{DF}, \mathrm{s}-\mathrm{BuOH}, \mathrm{H}_{2} \mathrm{O}$ & 0.319 & 1.75 & 0.993 \\
\hline $9 / 8 / 2004$ & $\mathrm{HM}, \mathrm{DF}, \mathrm{t}-\mathrm{BuOH}, \mathrm{H}_{2} \mathrm{O}$ & 0.454 & 2.02 & 0.998 \\
\hline
\end{tabular}

From this, it can be seen that the constants are very similar to that of diesel fuel with methanol appearing to be the closest to the commercial diesel fuel. This indicates that each of the extended diesel fuels vaporize in a similar way to diesel fuel requiring few if 
any changes in a diesel engine. Butanol has a curve different from all the other curves showing the solubility of butanol in diesel fuel. As seen in the graph in Appendix C, the temperatures remain lower for a larger percentage evaporated as the butanol boils off.

\section{ENERGY COMPARISON WITH ETHANOL}

The most common biofuel produced and used today is ethanol. In the United States, ethanol is made primary from corn. The energy comparison being made is between using corn to produce ethanol or feeding the same amount of corn to finishing hogs and then converting the manure into diesel fuel extender. The amount of energy estimated in the production of ethanol from corn must account for many different agricultural issues (29). These issues of growing the corn are neglected in this comparison, as it would require the same energy to grow the corn whether it is used to make ethanol or fed to hogs.

In the production of ethanol, current technology allows for 372-402 liters made

from $1 \mathrm{Mg}$ of corn. In this comparison, the average value of 387 liters of ethanol per $\mathrm{Mg}$ of corn is used (29). A crop yield of $7850 \mathrm{~kg}$ of corn per hectare, which is the average production of 1995-1997 in the nine major corn producing states, is used for this comparison (29). This one hectare of corn requires $41.6 \mathrm{GJ}$ of energy to make into ethanol. The resulting ethanol is worth $71.44 \mathrm{GJ}$ giving a net increase in energy of $29.84 \mathrm{GJ}(29)$. The energy ratio is 1.71 .

Distillers grain is produced as a by-product of the dry milling process and can be used a feed material for hogs. For each bushel (55lb) of corn dry milled to produce 
ethanol, $16 \mathrm{lbs}$ of distillers grain is produced. Based on several scientific papers, the highest amount of distillers grain recommended to be fed to finishing hog is $20 \mathrm{wt} \%$. Using the $7850 \mathrm{~kg}$ of corn to make ethanol, $2233 \mathrm{~kg}$ of distillers grain is produced and fed to hogs in a $20 \mathrm{wt} \%$ diet. This grain would raise 60 finishing hogs, but only $20 \%$ of their diet was distillers grain and only $20 \%$ or 12 hogs are assumed to be from the distillers grain.

To calculate the energy required for the Ag-Waste conversion process, there are two items requiring energy: heating the reactants and other processing energy. The energy to heat the reactants is determined by multiplying the amount of each reactant by the heat required to go from $25^{\circ} \mathrm{C}$ to $360^{\circ} \mathrm{C}$. First, the amount of each reactant must be determined. The "other processing energy" is described in a section below.

\subsection{Amount of Finishing Hogs and MANuRe Produced}

The hogs used in this comparison are finishing hogs with an initial weight of 150 Ibs and a finishing weight of $280 \mathrm{lbs}$. These hogs consume a diet that ranges from $78 \%$ to $85 \%$ corn. For this comparison, three values were used: $78 \%$ corn, $82 \%$ corn and $85 \%$ corn. With each of these diets, a consumption ratio of $3.2 \mathrm{lbs}$ feed to $1 \mathrm{lb}$ of weight gain was used. In the chart below you can see the amount each hog would consume from $150 \mathrm{lbs}$ to $280 \mathrm{lbs}$. 
Table 9: Varying Corn Percentage for Finishing Hog Diets

\begin{tabular}{|l|l|l|l|}
\hline Diet & $78 \%$ corn & $82 \%$ corn & $85 \%$ corn \\
\hline Feed consumed per hog (lb) & 416 & 416 & 416 \\
\hline Corn consumed per hog (lb) & 324.5 & 341.1 & 353.6 \\
\hline Manure produced per hog (Ib) & 291.2 & 291.2 & 291.2 \\
\hline Hogs raised & 53 hogs & 50 hogs & 48 hogs \\
\hline Hogs assumed from corn & 42 hogs & 42 hogs & 42 hogs \\
\hline
\end{tabular}

The digestibility of corn is $70 \%$ on a dry basis. For our comparison, $7850 \mathrm{~kg}$ of corn are fed to the hogs in the various percentages. Since the compassion being done is between ethanol that is only made from corn, the amount of dry manure produced will be $30 \%$ of the corn or $2355 \mathrm{~kg}$. From each of these percentages the number of hogs raised is shown in Table 9. The best diesel fuel extender process case was used for this comparison (propanol) and the ratios of reactants and products produced are based on that reaction found in Table 5.

Table 10: Reactant amounts in Ethanol Comparison

\begin{tabular}{|c|c|c|c|}
\hline Manure (kg) & Water $(\mathrm{kg})$ & Propanol (kg) & Diesel Fuel (kg) \\
\hline 2355 & 1413 & 942 & 3532 \\
\hline
\end{tabular}

\subsection{Heat RequiRed to Reach Reaction Temperature}

There are four reactants: water, diesel fuel, propanol, and hog manure. Each of these reactants is heated from $25^{\circ} \mathrm{C}$ to $360^{\circ} \mathrm{C}$. The heat capacity of each reactant was 
found as a function of temperature and the heat of vaporization. Using the following equation

$$
\text { Heat }=\int_{T_{o}}^{T_{b}} C_{p, \text { liquid }} d T+\Delta H_{\text {vap }}+\int_{T_{b}}^{T_{f}} C_{p, \text { vapor }} d T
$$

where $C_{p}$ is the heat capacity for the liquid or vapor, $T_{0}$ is the initial temperature, $T_{b}$ is the normal boiling point, $\mathrm{T}_{\mathrm{f}}$ is the final temperature, and $\Delta \mathrm{H}_{\mathrm{vap}}$ is the heat of vaporization at $T_{b}$.

Water

Heat $_{w}=\int_{298}^{373} 4.184 d T+22.58+\int_{373}^{633}\left(30.09+6.832(T / 1000)+6.793(T / 1000)^{2}-2.534(T / 1000)^{3}\right) d T=3151 \frac{\mathrm{kJ}}{\mathrm{kg}}$

Liquid Heat Capacity (30)

Heat of Vaporization (31)

Vapor Heat Capacity (32)

Diesel Fuel

$$
\text { Heat }_{D F}=\int_{298}^{466}(0.76+0.000335 T) d T+244+\int_{466}^{633}(0.136+0.00378 T) d T=1131 \frac{\mathrm{kJ}}{\mathrm{kg}}
$$

Liquid Heat Capacity, Heat of Vaporization, and Vapor Heat Capacity (33)

Boiling point temperature is taken as the point at which $50 \%$ of the diesel evaporated in simulated distillation. This temperature was $193^{\circ} \mathrm{C}$. 
Propanol

$$
\begin{aligned}
& \text { Heat }_{\mathrm{PrOH}}=\int_{298}^{370} 2.2 d T+786.5+\left(\int_{370}^{633}-1.307+0.09235 T-5.8 \times 10^{-5} T^{2}+1.414 \times 10^{-8} T^{3} d T\right) \times \frac{4.184 \mathrm{~J}}{c a l} \times \frac{\mathrm{mole}}{60 \mathrm{~g}} \\
& \text { Heat }_{\mathrm{PrOH}}=1938.5 \frac{\mathrm{kJ}}{\mathrm{kg}}
\end{aligned}
$$

Liquid Heat Capacity and Heat of Vaporization (34)

Vapor Heat Capacity (35)

Hog Manure

A value for manure could not be found. A substitute of wood is being used for the heat capacity. The heat capacity was given in degrees Fahrenheit.

$$
\text { Heat }_{\text {HM }}=\int_{77}^{680}(0.25+0.0006 T) d T \times \frac{4.184 \mathrm{~J}}{\mathrm{cal}}=1776 \frac{\mathrm{kJ}}{\mathrm{kg}}
$$

Heat Capacity (36)

The total energy required to heat the reactants up to reaction temperature was $19.2 \mathrm{GJ}$.

\subsection{Energy RequiRed to Process Ag-WAste}

The amount of energy needed to convert the animal waste is not easily calculated as the process is still in the early stages. For this reason, the dry-mill ethanol process was considered to be a similar method of production or separation. The drymill ethanol uses $1.09 \mathrm{kWhr}$ per gallon ethanol produced of electricity (no heating included) (37). To translate this to diesel fuel extender, the number of gallons of fuel produced is determined and then the electrical energy required is calculated. The energy required is $5.24 \mathrm{GJ}$.

The total energy required to produce diesel fuel extender is given in Table 11. 
Table 11: Total Energy Required for the Production of Diesel Fuel Extender

\begin{tabular}{|l|l|}
\hline Heat Required & $19.2 \mathrm{GJ}$ \\
\hline Process Energy & $5.2 \mathrm{GJ}$ \\
\hline Total Energy Required & $24.4 \mathrm{GJ}$ \\
\hline
\end{tabular}

\subsection{ENERGY PRODUCED}

The energy produced is found in the form of three fuels and phosphate fertilizer. The three fuels produced are the extended diesel fuel, the black solid, and the aqueous phase. In Table 12, the heating values and total energy produced are shown. Since diesel fuel is a reactant in the process, the amount of energy it contains entering the system is subtracted from the fuel energy produced. In the diesel fuel extender process, the ash (phosphate salts) is collected and could then be used as fertilizer. To account for this production, the ash made adds energy to the process, since it did not have to be produced though normal means. Its energy cost of production is shown in Table 12. The total energy produced is $50.24 \mathrm{GJ}$. 
Table 12: Total Energy Produced in the Production of Diesel Fuel Extender

\begin{tabular}{|c|c|c|c|}
\hline & Amount (kg) & Heating Value (kJ/kg) & Energy (GJ) \\
\hline Diesel Fuel Extender & 4300.2 & 42135 & 181.2 \\
\hline Black Solid & 569.9 & 25089 & 14.3 \\
\hline Aqueous Phase & 2265.5 & 4209 & 9.5 \\
\hline Phosphate Salt & 362.67 & 9275 & 3.4 \\
\hline & & & \\
\hline Diesel Fuel & 3532.50 & 44769 & 158.1 \\
\hline & & & 50.2 \\
\hline Total Energy Produced & & & \\
\hline
\end{tabular}

The net energy produced with the diesel fuel extender process is $25.8 \mathrm{GJ}$.

\subsection{COMPARISON WITH ETHANOL}

An overall comparison of the diesel fuel extender process and ethanol is shown in Table 13. The ethanol produces more energy per hectare $(7850 \mathrm{~kg})$ of corn but required more energy to produce as well. The ratio of energy produced over energy required shows that the animal waste conversion process is competitive with ethanol and feeds more finishing hogs. 
Table 13: Energy Comparison of Diesel Fuel Extender Process and Ethanol

\begin{tabular}{|c|c|c|}
\hline & Ethanol & Animal Waste Conversion Process \\
\hline Energy Required (GJ) & 41.6 & 24.4 \\
\hline Energy Produced (GJ) & 71.44 & 50.2 \\
\hline Net Energy (GJ) & 29.84 & 25.8 \\
\hline Energy Ratio & 1.71 & 2.05 \\
\hline Hogs Produced & 12 & 42 \\
\hline
\end{tabular}

\section{SUMMARY AND CONCLUSIONS}

From the original work completed on this process, two main problems arose: the amount of ash present in the extended diesel fuel and the viscosity of the extended diesel fuel. The presence of diesel fuel as a reactant was thought to allow the entrained ash to be free due to parts of the diesel fuel being at supercritical conditions at the reaction temperature and pressure of $360^{\circ} \mathrm{C}$ and $3100 \mathrm{psi}$. The results support this theory. When the diesel fuel was added as a reactant, the ash was released as water soluble and water insoluble phosphate salts. The extender produced also dissolved directly into the diesel fuel so no surfactant was required. The resulting extended diesel fuel was ash free and low in viscosity (without the surfactant present).

The problem then became the amount of extender present in the diesel fuel. When using a surfactant, $20 \%$ extender was mixed with $5 \%$ surfactant and $75 \%$ diesel fuel. Using the new method, there was only $4.8 \%$ extender present in the diesel fuel. The addition of various alcohols to the reactant mixture allowed more of the extender to 
be dissolved directly into the diesel fuel, with propanol providing the highest amount at $20 \%$ extender.

The new extended diesel fuel needed to be compared to commercial diesel fuel. Heating values of the fuels were determined and found to be similar to commercial diesel fuel, although slightly lower. Simulated distillation analysis was also preformed to determine the evaporation rate of the various fuel and compared to the diesel fuel extender. It was also found to be similar. The final test was to run a diesel engine on the new extended diesel fuel. The engine ran with no modifications. From the analysis completed, the extended diesel fuel could be a suitable source of biodiesel fuel in the future.

Finally, the diesel fuel extender proves to be better than the conversion process of corn in the United States. The energy ratio for the ethanol process is 1.71 and the diesel fuel extender process is 2.05 . More energy is produced as fuel by feeding the corn to finishing hogs and then converting their manure, and an additional 30 pigs were raised. 


\section{RECOMMENDATIONS}

Although the extended diesel fuel is similar to that of commercial diesel fuel, further ASTM testing should be completed. The ATSM tests that were performed on the original extended diesel fuel should be repeated with the new extended diesel fuel. Reactions should be run at various alcohol concentrations, time frames, and temperatures to determine the kinetic parameters for the reaction in order to design a reactor for this system. Separation techniques should be tried to separate the water from the small chain organic acids and alcohols in the aqueous phase. The resulting small chain organic acids and alcohols should be investigated for possible fuel uses as well. As the diesel fuel extender process is explored in more detail, the ethanol comparison should be reevaluated to verify the results found. 


\section{WORKS CITED}

1. "North Carolina and the Global Economy: Hog Production Overview." Fall 2004. Duke University. Aug. 18, 2005. <http://www.duke.edu/web/soc142/hogfarming/>

2. "Chapter 4: Agricultural Waste Characteristics." Agricultural Waste Management Field Handbook. US Department of Agriculture, Apr 2002.

3. "Background Statistics on US Broiler Industry." Economic Research Service. Sept. 16, 2005. <http://www.ers.usda.gov/>

4. "Part II: Changes in the United States Dairy Industry, 1991-2002." USDA: Dairy 2002. United States Department of Agriculture. June 2003.

5. "USDA Livestock Data." Cattle Fax. Sept. 16, 2005. <http://www.cattle-fax.com/>

6. Olin, Dirk and Vikki Kratz. "Chicken Sick." Mother Jones. 23 (1998): 19

7. Mallin, Michael and Lawrence Cahoon. "Industrialized Animal Production: A Major Source of Nutrient and Microbial Pollution to Aquatic Ecosystems." Population and Environment. 24 (2003): 369-386

8. Zahn, J.A., J.L. Hatfield, Y.S. Do, A.A. DiSpirito, D.A. Laird, and R.F. Pfeiffer. "Characterization of Volatile Organic Emissions and Wastes from a Swine Production Facility". Journal of Environmental Quality, 26 (1997) 1687-1969

9. He, Bingjun. Thermochemical Conversion of Swine Manure to Produce Oil and Reduce Waste. University of Illinois at Urbana-Champaign. (2000) PhD Dissertation

10.Zhang, R.H. and F. Lei. "Chemical Treatment of Animal Manure for Solid-Liquid Separation." Transactions of ASAE. 41 (1998):1103-1108

11. Henriksen, K. et al. "Separation of Liquid Pig Manure by Flocculation and Ion Exchange." Journal of Agricultural Engineering Research. 69 (1998): 127-131

12. Goldstein, Irving. Organic Chemicals from BioMass. 1981. CRC Press Inc: Boca Raton, FL

13. Zhang, Y., G. Riskowski, and T. Funk. "Thermochemical Conversion of Swine Manure to Produce Fuel and Reduce Waste." Final Report submitted to Illinois Council on Food and Agricultural (1999)

14. Davis, Nicole. "Turkey Fuel? Factory to Turn Guts into Crude Oil." National Geograhic News. Oct. 4, 2004 <http://news.nationalgeographic.com/news/2003/11/1125_031125_turkeyoil.html $>$

15. Molton, P., A. Fassbender, and M. Brown. "STORS: The Sludge-to-Oil Reactor System." Final Report submitted to Water Engineering Research Laboratory (1986)

16. Annual Energy Review:2004. Department of Energy. Sept 26, 2005. $<$ http://www.doe.gov>

17. International Energy Outlook: 2004. Department of Energy. Sept 26, 2005. $<$ http://www.doe.gov>

18. GreenPeace. Fueling Flobal Warming: Federal Subsidies to Oil in the United States. Oct. 31, 2005. < http://www.greenpeace.org/international/press/reports/fueling-global-warming> 
19. "Nuclear Power in France". Energy Information Agency. Sept 28, 2005. $<$ http://greennature.com/article744.html>

20. Gerpen, Jon Van. "Biodiesel Processing and Production." Fuel Processing Technology. 86 (2005): 1097-1107.

21. Weeks, Jennifer. "Building an Energy Economy on Biodiesel." BioCycle. July 2005: 67-69

22. Freedman, B., E.H. Pryde, and T.L. Mounts. "Variables Affecting the Yields of Fatty Esters from Tranesterified Vegetable Oils." JAOCS. 61 (1984): 1638-1643

23. Boocock, B.G.B., S.K. Konar, and W. Zhou. "Ethyl Esters from the Single Phase Base Catalyzed Ethanolysis of Vegetable Oils. JAOCS. 80 (2003) 367-371

24. Boocock, B.G.B. "Single Phase Process for the Production of Fatty Acid Methyl Esters from Mixtures of Triglycerides and Fatty Acids." Canadian Patent No. 2,381,394. Feb. 22, 2001.

25. Canakci, M. "Performance and Emission Characteristics of Biodiesel from Soybean Oil." IMechE. 219 (2005): 915-922.

26. Launder, Kelly. "From Promise to Purpose: Opportunities and Constraints for Ethanol-Based Transportation Fuels." (2001) Masters of Science Research Report. Michigan State University.

27. "How is ethanol made?". American Coalition for Ethanol. March 30, 2006. $<$ www.ethanol.org>

28. RFA. "Ethanol Industry Surges to All Time Production Records in 2000." Ethanol Report. 1/25/01

29. Dias de Oliveria, Marcelo, Burton Vaughan, Edward Rykiel Jr. "Ethanol as Fuel: Energy, Carbon Dioxide Balances, and Ecological Footprint." BioScience. 55 (2005): 593-602.

30. "NIST Stardard reference Database Number 69." National Institute of Standards and Technology. April 18, 2006. <http://webbook.nist.gov/chemistry>

31. Lide, David, Ed. CRC Handbook of Chemistry and Physics 85th Edition. 2004 CRC Press LLC, Boca Raton FL

32. Speight, James. Perry's Standard Tables and Formulas for Chemical Engineers. 2003 McGraw-Hill New York, NY

33. Borman, Gary, Kenneth Ragland. Combustion Engineering 1998. McGraw-Hill Companies Inc. New York, NY

34. Celanese Chemicals Product Description. World Wide Web. $<$ http://info.chemvip.com> 3/22/06

35. Sandler, Stanley. Chemical Engineering Thermodynamics 2nd Edition. 1989. John Wiley and Sons Inc. New York, NY.

36. Wood Handbook: Wood as an Engineering Material. Forest Products Laboratory, Forest Services, US Dept of Agriculture. 1987. Washington DC

37. Shapouri, H, J Duffield, A McAloon and M Wang. "The Net Energy Balance of Corn-Ethanol." 2003. US Department of Agriculture. 


\section{APPENDIX A}

ASTM Method Description 


\begin{tabular}{|c|c|c|}
\hline Property & Test Method & Description \\
\hline Density & $\begin{array}{l}\text { ASTM D } 287-A P I \\
\text { Gravity }\end{array}$ & $\begin{array}{l}\text { This test method covers the determination by } \\
\text { means of a glass hydrometer of the API gravity } \\
\text { of crude petroleum and petroleum products } \\
\text { normally handled as liquids and having a Reid } \\
\text { vapor pressure (Test Method D323) of } 26 \mathrm{psi} \\
(180 \mathrm{kPa} \text { ) or less. Gravities are determined at } \\
60^{\circ} \mathrm{F}\left(15.56^{\circ} \mathrm{C}\right) \text {, or converted to values at } 60^{\circ} \mathrm{F} \text {, } \\
\text { by means of standard tables. These tables are } \\
\text { not applicable to nonhydrocarbons or essentially } \\
\text { pure hydrocarbons such as the aromatics. }\end{array}$ \\
\hline Flash Point & $\begin{array}{l}\text { ASTM D 93-Rash } \\
\text { Point by Pensky- } \\
\text { Martens Closed Cup } \\
\text { Tester }\end{array}$ & $\begin{array}{l}\text { The sample is stiffed and heated at a slow, } \\
\text { constant rate in a closed cup. At intervals, the } \\
\text { cup is opened and an ignition source is moved } \\
\text { over the top of the cup. The flash point is the } \\
\text { lowest temperature at which the application of } \\
\text { the ignition source causes the vapors above the } \\
\text { liquid to ignite. }\end{array}$ \\
\hline $\begin{array}{l}\text { Water and } \\
\text { Sediment }\end{array}$ & $\begin{array}{l}\text { ASIM D } 2709-\text { Water } \\
\text { and Sediment in Middle } \\
\text { distillate Fuels by } \\
\text { Centrifuge }\end{array}$ & $\begin{array}{l}\text { Water and sediment are contaminants. In this } \\
\text { test, a } 100 \text { nil sample is centrifuged under } \\
\text { specified conditions in a calibrated tube. The } \\
\text { amount of sediment and water that settles to the } \\
\text { bottom of the tube is read directly using the } \\
\text { scale on the tube. }\end{array}$ \\
\hline Viscosity & $\begin{array}{l}\text { ASTM D } 445- \\
\text { Kinematic Viscosity of } \\
\text { Transparent and } \\
\text { Opaque Liquids }\end{array}$ & $\begin{array}{l}\text { The sample is placed in a calibrated capillary } \\
\text { glass viscometer tube and held at a closely } \\
\text { controlled temperature. The time required for a } \\
\text { specific volume to flow through the capillary } \\
\text { under gravity is measured. This time is } \\
\text { proportional to the kinematic viscosity of the } \\
\text { sample. }\end{array}$ \\
\hline Ash & $\begin{array}{l}\text { ASTM D } 482-\text { Ash } \\
\text { from Petroleum } \\
\text { Products }\end{array}$ & $\begin{array}{l}\text { The sample is placed in a crucible, ignited and } \\
\text { allowed to burn. The carbonaceous residue is } \\
\text { heated further in a muffle furnace to convert all } \\
\text { the carbon to carbon dioxide and all the mineral } \\
\text { salts to oxides (ash). The ash is then cooled } \\
\text { and weighed. }\end{array}$ \\
\hline Sulfur & $\begin{array}{l}\text { ASIM D } 2622-\text { Sulfur } \\
\text { in Petroleum Products } \\
\text { by X-ray Spectrometry }\end{array}$ & $\begin{array}{l}\text { The sample is placed in an } x \text {-ray beam and the } \\
\text { intensity of the sulfur } x \text {-ray fluorescence is } \\
\text { measured. }\end{array}$ \\
\hline $\begin{array}{l}\text { Copper } \\
\text { Strip } \\
\text { Corrosion }\end{array}$ & $\begin{array}{l}\text { ASTM D } 130- \\
\text { Detection of Copper } \\
\text { Corrosion from } \\
\text { Petroleum Products by } \\
\text { the Copper Strip } \\
\text { Tarnish Test }\end{array}$ & $\begin{array}{l}\text { A polished copper strip is immersed in the } \\
\text { sample for three hours at } 122^{\circ} \mathrm{F}\left(50^{\circ} \mathrm{C}\right) \text { and then } \\
\text { removed and washed. The condition of the } \\
\text { copper surface is qualitatively rated by } \\
\text { comparing it to standards. }\end{array}$ \\
\hline
\end{tabular}




\begin{tabular}{|l|l|l|}
\hline Cetane & ASTM D 613- \\
Number & $\begin{array}{l}\text { Standard Test Method } \\
\text { for Cetane Number of } \\
\text { Diesel Fuel Oil }\end{array}$ & $\begin{array}{l}\text { The method involves running the fuel in a single } \\
\text { cylinder engine with a continuously variable } \\
\text { compression ratio under a fixed set of } \\
\text { conditions. }\end{array}$ \\
\hline
\end{tabular}




\section{APPENDIX B}

Chromatography Result Example 

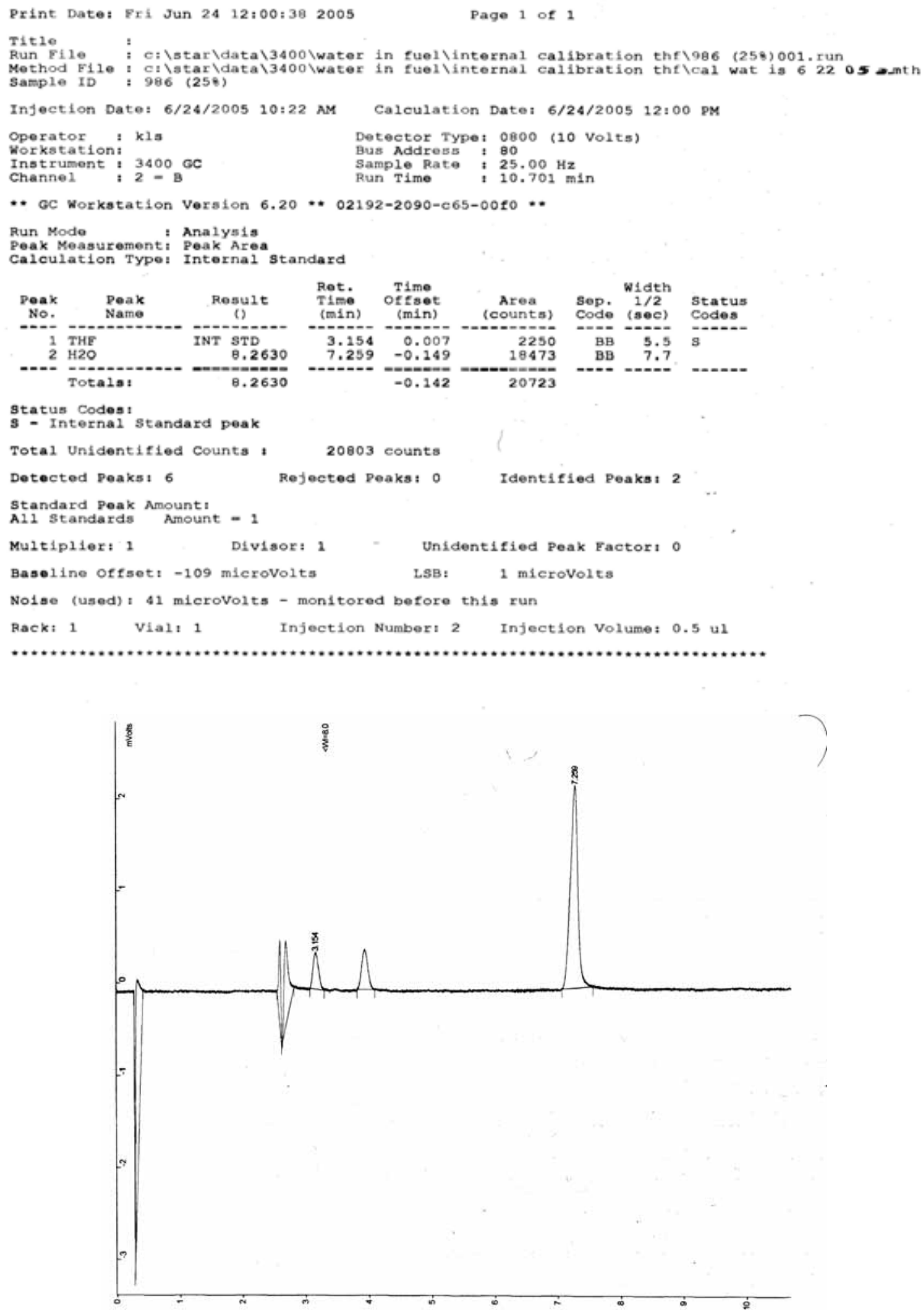


\title{
APPENDIX C
}

\author{
Simulated Distillation Curves
}




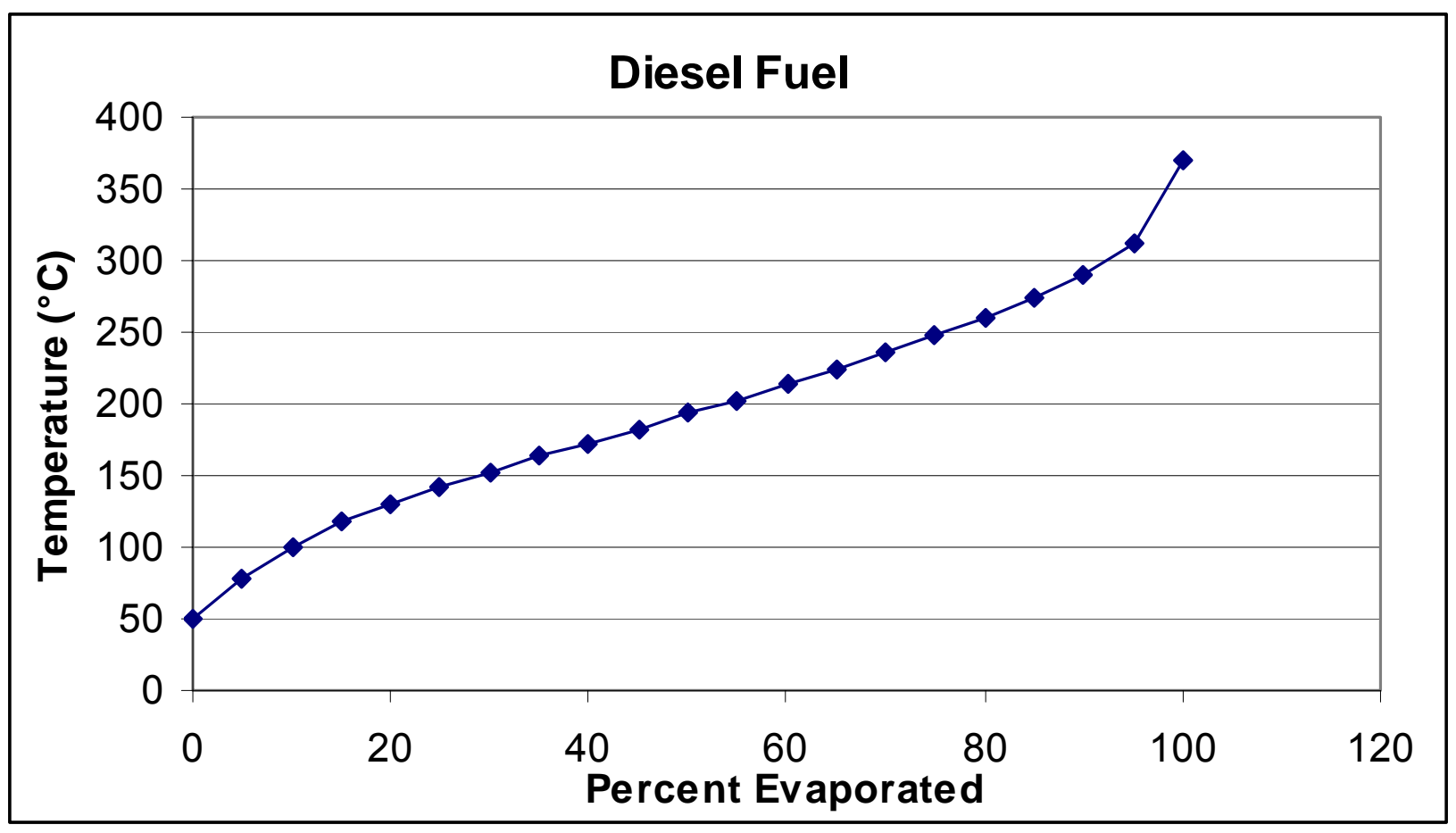

$\mathrm{HM}, \mathrm{DF}, \mathrm{H}_{2} \mathrm{O}$

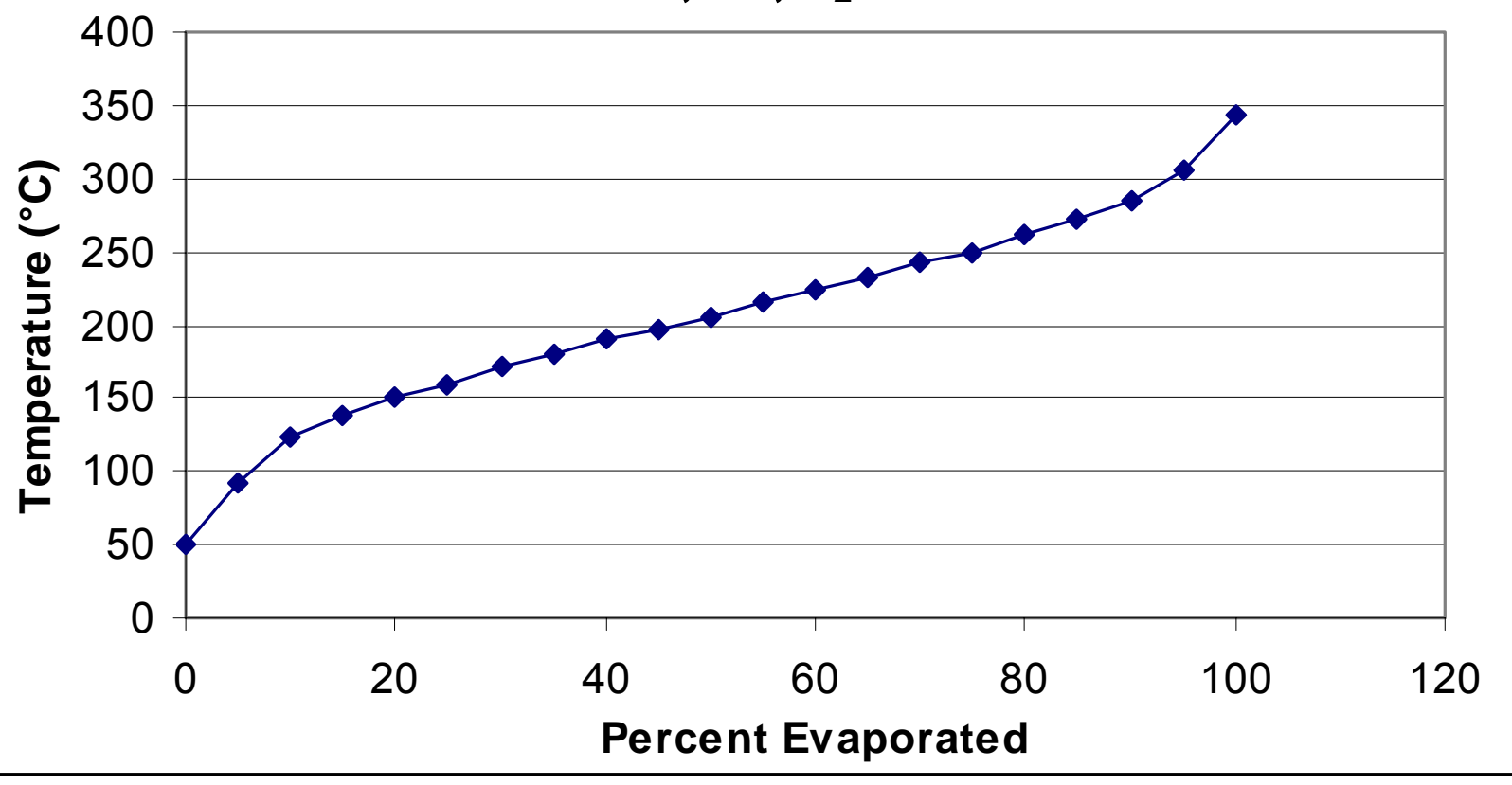




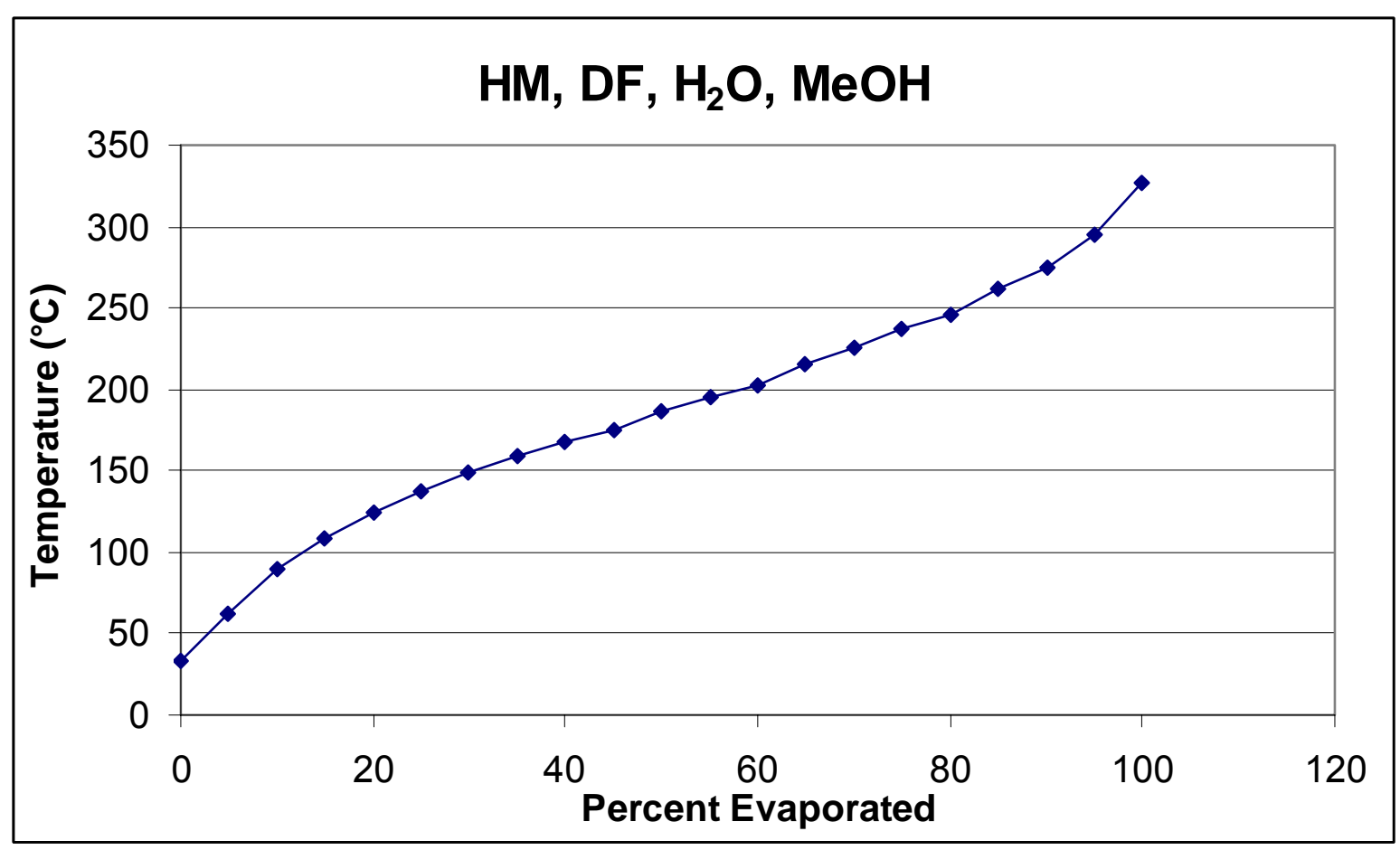

\section{$\mathrm{HM}, \mathrm{DF}, \mathrm{H}_{2} \mathrm{O}$, EtOH}

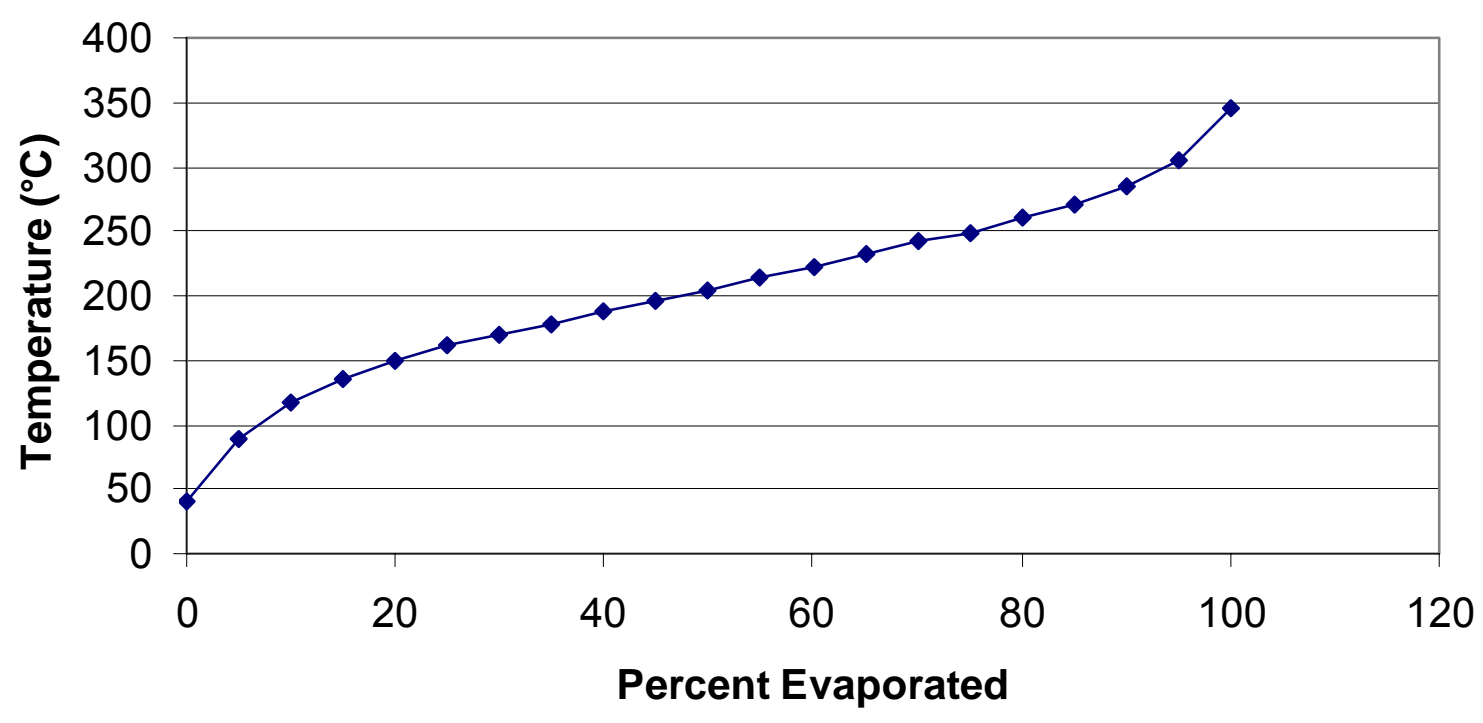




\section{$\mathrm{HM}, \mathrm{DF}, \mathrm{H}_{2} \mathrm{O}$, PrOH}

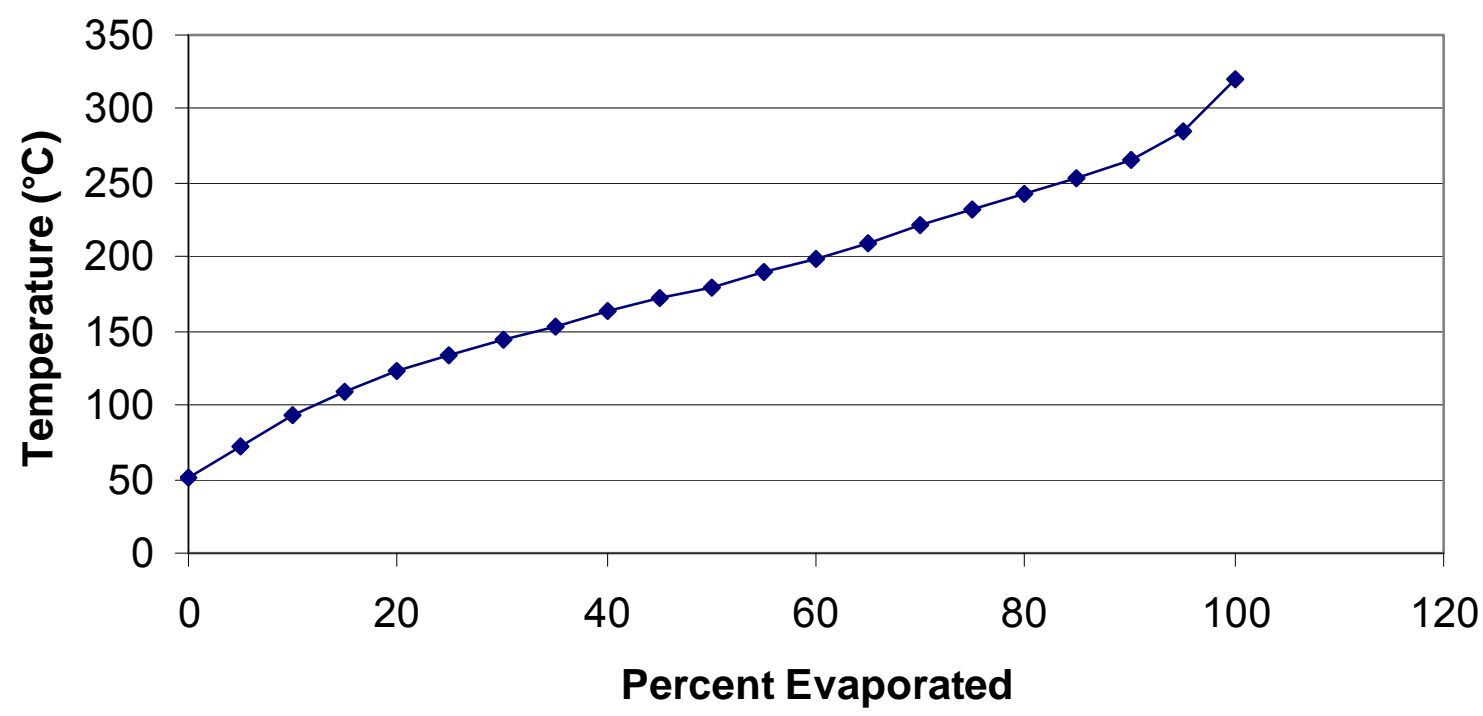

$\mathrm{HM}, \mathrm{DF}, \mathrm{H}_{2} \mathrm{O}$, BuOH

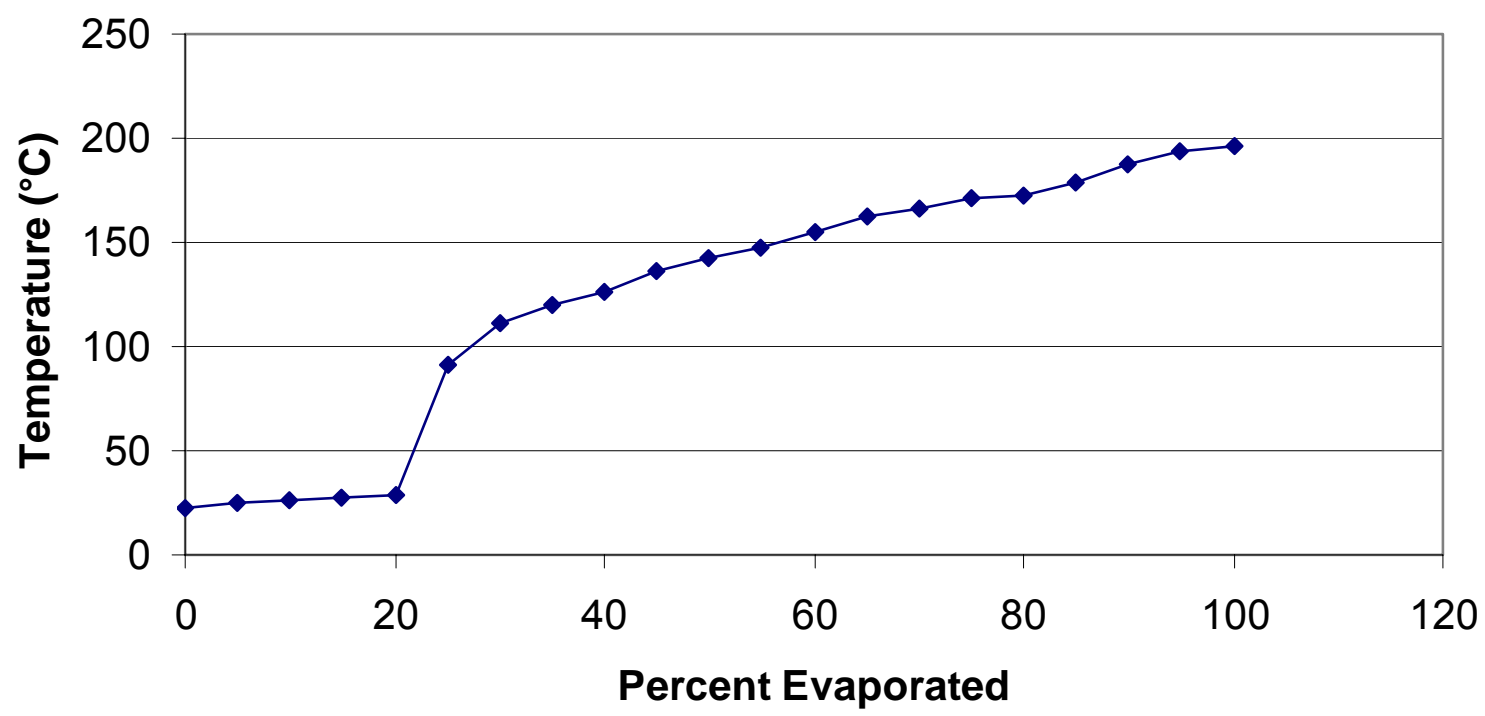




\section{HM, DF, $\mathrm{H}_{2} \mathrm{O}$, s-BuOH}

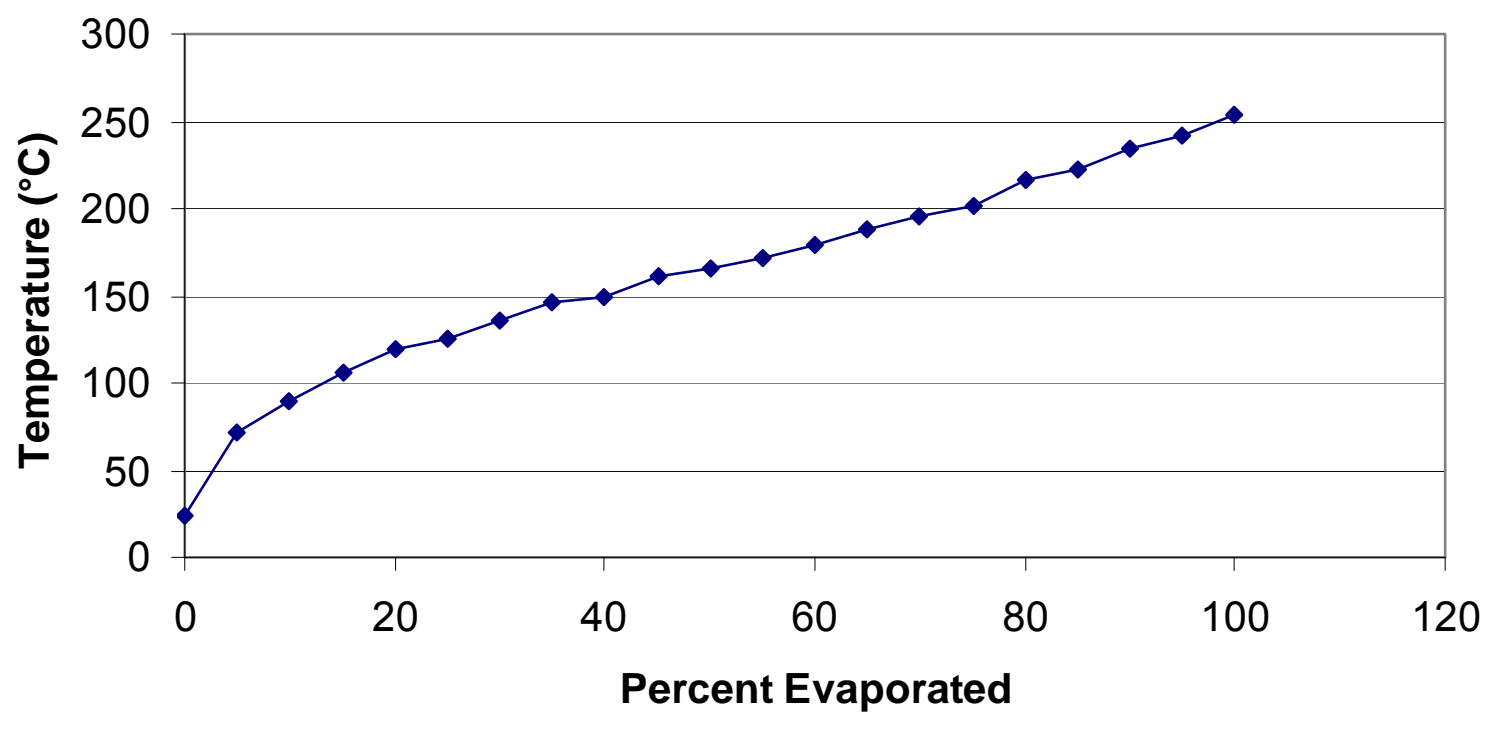

$\mathrm{HM}, \mathrm{DF}, \mathrm{H}_{2} \mathrm{O}$, t-BuOH

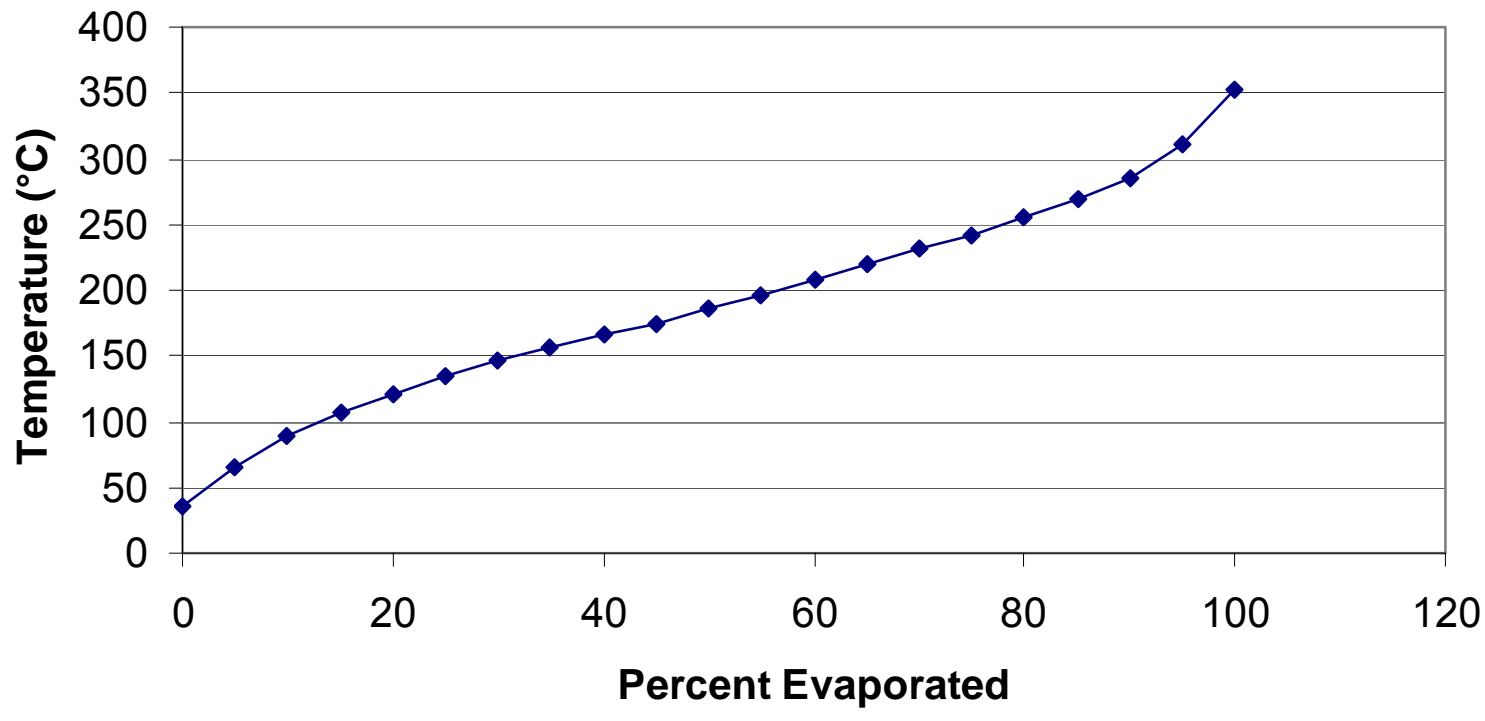




\section{APPENDIX D}

Fitting of Data to Model 

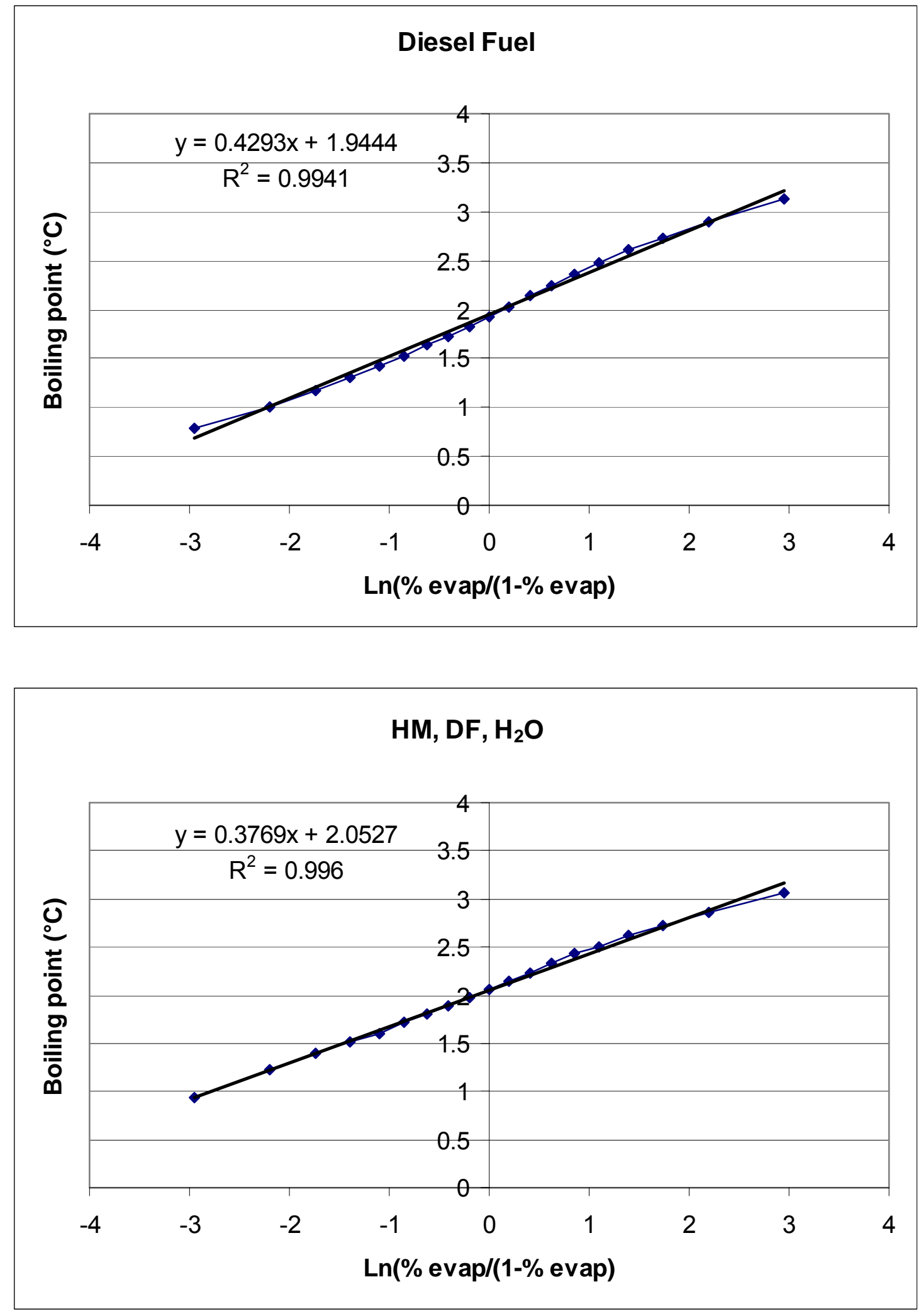

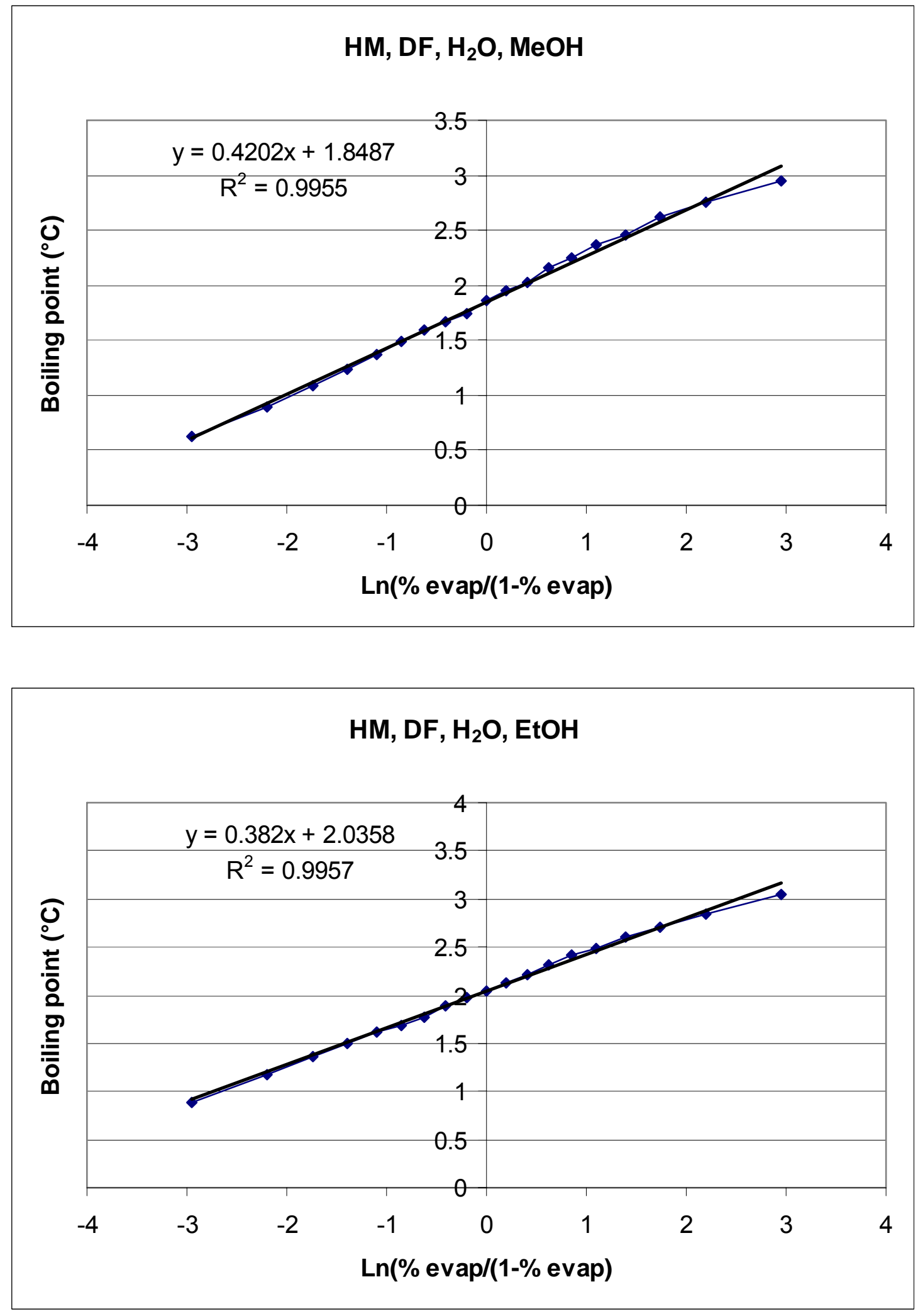

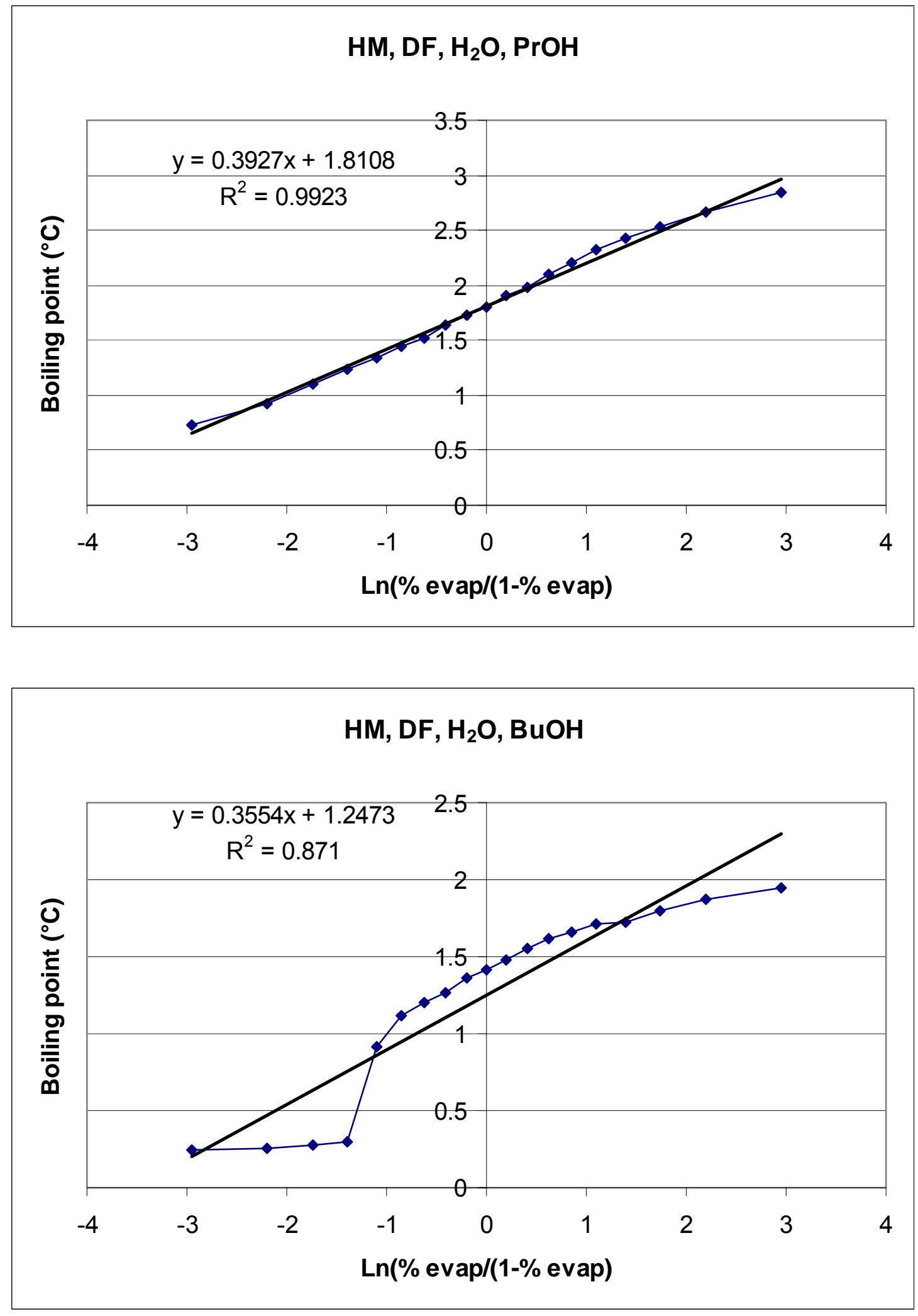

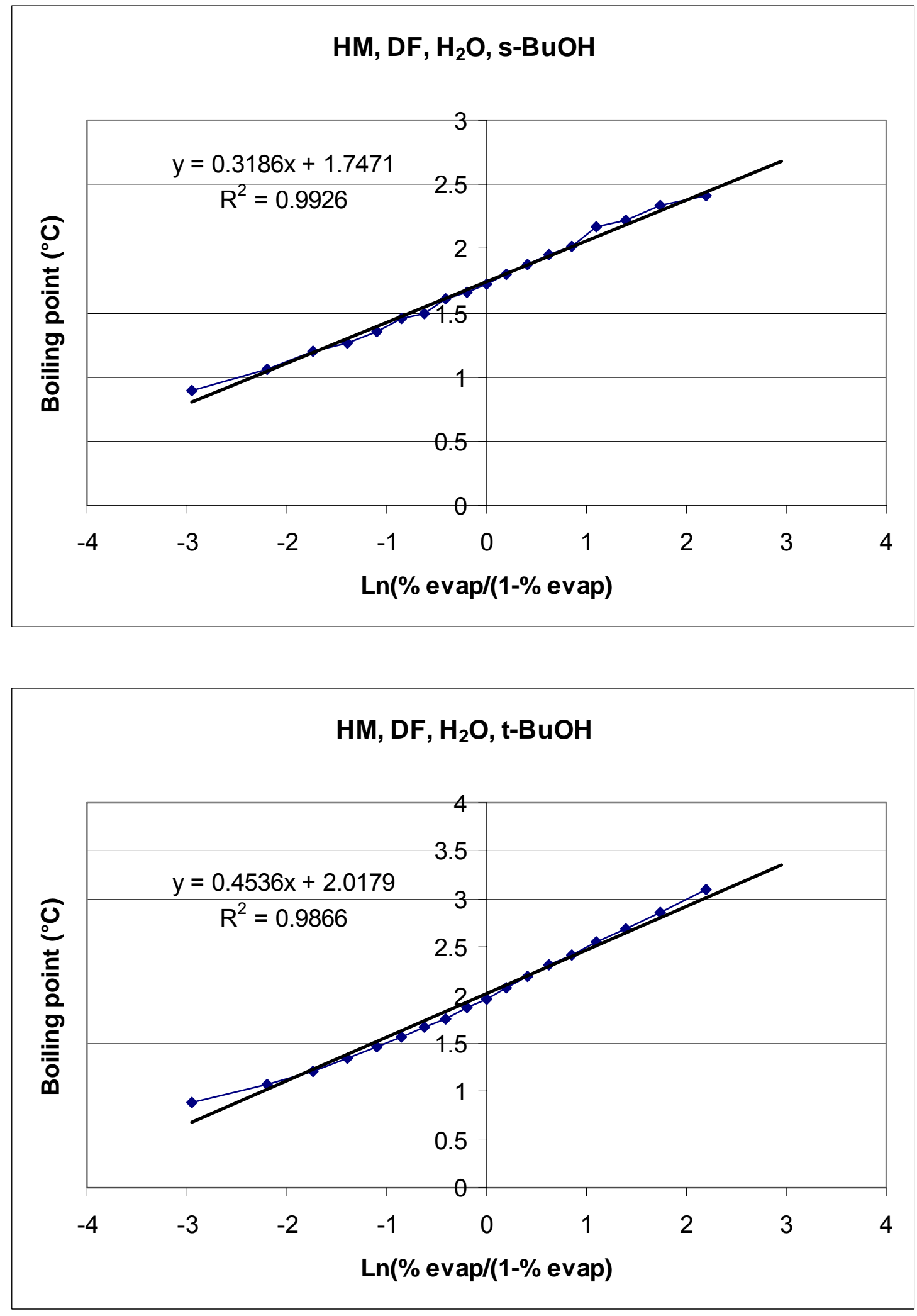


\section{APPENDIX E}

Material Balance for Each Reaction Shown in Table 3 and Table 5 


\begin{tabular}{|c|c|c|c|}
\hline \multicolumn{4}{|l|}{ Reactants } \\
\hline Hog Manure & 500.1 & & \\
\hline Water & 500.36 & & \\
\hline Diesel Fuel & 735.98 & & \\
\hline Total & 1736.44 & & \\
\hline Gas Collection & Weight Before Venting & Weight After Venting & Difference \\
\hline Vent Bag & 321 & 335.37 & 14.37 \\
\hline Catch Bottle & 167.5 & 176.54 & 9.04 \\
\hline Total & & & 23.41 \\
\hline Assume gas amount & & & 124.46 \\
\hline Empting of Reactor & Weight Before Empting & Weight After Empting & Difference \\
\hline Catch Bucket & 135.45 & 1734.65 & 1599.2 \\
\hline Paper Towels & 8.94 & 21.72 & 12.78 \\
\hline Total & & & 1611.98 \\
\hline \multicolumn{4}{|l|}{ Material Balance } \\
\hline Gas Weight & 124.46 & & \\
\hline Solid and Liquid Weight & 1611.98 & & \\
\hline Total & 1736.44 & & \\
\hline Separation of Liquid and Solid & Weight Before & Weight After & Difference \\
\hline Liquid Bucket & 121.02 & 1540.22 & 1419.2 \\
\hline Screen & 41.2 & 48.14 & 6.94 \\
\hline Solids Bucket & 135.45 & 308.51 & 173.06 \\
\hline Total & & & 1599.2 \\
\hline Liquid Separation & Weight Before & Weight After & Difference \\
\hline Extender Beaker & 433.42 & 1205.39 & 771.97 \\
\hline Water Beaker & 432.12 & 1068.06 & 635.94 \\
\hline Vacuum Flask & 622.1 & 1193.41 & 571.31 \\
\hline Filter for Gray Solid & 111.3 & 175.93 & 64.63 \\
\hline Crystal Collection & Weight Before Drying & Weight After Drying & Difference \\
\hline Pan and Water & 752.29 & 226.21 & 526.08 \\
\hline \multicolumn{4}{|c|}{ Dried Aqueous Phase rinsed with Methanol and Crystals Collected } \\
\hline & \begin{tabular}{|l|} 
Weight Before \\
\end{tabular} & Weight After & \\
\hline Vial for Crystals & 181.82 & 193.21 & 11.39 \\
\hline Amount Evaporated or Rinsed off & 559.92 & & \\
\hline \multicolumn{4}{|l|}{ Solid Separation } \\
\hline \multicolumn{4}{|l|}{ THF Rinse } \\
\hline \multirow[t]{2}{*}{ Amount of THF Added } & 192.98 & & \\
\hline & Weight Before & Weight After Difference & \\
\hline Vacuum Flask & 718.38 & 953.01 & 234.63 \\
\hline Filter and Solids & 110.35 & 241.76 & 131.41 \\
\hline THF Soluble & 41.65 & & \\
\hline THF Insoluble Dried & 68.58 & & \\
\hline Amount of Volatiles & 62.83 & & \\
\hline All weights shown in grams. & & & \\
\hline
\end{tabular}




\begin{tabular}{|c|c|c|c|}
\hline \multicolumn{4}{|l|}{ Reactants } \\
\hline Hog Manure & 501.71 & & \\
\hline Water & 300.3 & & \\
\hline Methanol & 204.11 & & \\
\hline Diesel Fuel & 634.06 & & \\
\hline Total & 1640.18 & & \\
\hline Gas Collection & Weight Before Venting & Weight After Venting & Difference \\
\hline Vent Bag & 321.09 & 332.4 & 11.31 \\
\hline Catch Bottle & 165.52 & 173.93 & 8.41 \\
\hline Total & & & 19.72 \\
\hline Assume gas amount & & & 153.05 \\
\hline Empting of Reactor & Weight Before Empting & Weight After Empting & Difference \\
\hline Catch Bucket & 134.93 & 1613.92 & 1478.99 \\
\hline Paper Towels & 9.07 & 17.21 & 8.14 \\
\hline Total & & & 1487.13 \\
\hline \multicolumn{4}{|l|}{ Material Balance } \\
\hline Gas Weight & 153.05 & & \\
\hline Solid and Liquid Weight & 1487.13 & & \\
\hline Total & 1640.18 & & \\
\hline Separation of Liquid and Solid & Weight Before & Weight After & Difference \\
\hline Liquid Bucket & 134.85 & 1471.79 & 1336.94 \\
\hline Screen & 40.5 & 50.37 & 9.87 \\
\hline Solids Bucket & 137.23 & 269.41 & 132.18 \\
\hline Total & & & 1478.99 \\
\hline Liquid Separation & Weight Before & Weight After & Difference \\
\hline Extender Beaker & 433.58 & 1138.34 & 704.76 \\
\hline Water Beaker & 430.86 & 1054.86 & 624 \\
\hline Vacuum Flask & 622.1 & 1165.6 & 543.5 \\
\hline Filter for Gray Solid & 111.3 & 191.8 & 80.5 \\
\hline Crystal Collection & Weight Before Drying & Weight After Drying & Difference \\
\hline Pan and Water & 741.29 & 239.86 & 501.43 \\
\hline \multicolumn{4}{|c|}{ Dried Aqueous Phase rinsed with Methanol and Crystals Collected } \\
\hline & Weight Before & Weight After & \\
\hline Vial for Crystals & 182.3 & 191.8 & 9.5 \\
\hline Amount Evaporated or Rinsed off & 534 & & \\
\hline \multicolumn{4}{|l|}{ Solid Separation } \\
\hline \multicolumn{4}{|l|}{ THF Rinse } \\
\hline \multirow{2}{*}{ Amount of THF Added } & 185.3 & & \\
\hline & Weight Before & Weight After Difference & \\
\hline Vacuum Flask & 718.65 & 947.45 & 228.8 \\
\hline Filter and Solids & 69.56 & 158.24 & 88.68 \\
\hline THF Soluble & 43.5 & & \\
\hline THF Insoluble Dried & 69.59 & & \\
\hline Amount of Volatiles & 19.09 & & \\
\hline All weights shown in grams. & & & \\
\hline
\end{tabular}




\begin{tabular}{|c|c|c|c|}
\hline \multicolumn{4}{|l|}{ Reactants } \\
\hline Hog Manure & 500.1 & & \\
\hline Water & 300.32 & & \\
\hline Ethanol & 200.2 & & \\
\hline Diesel Fuel & 644.19 & & \\
\hline Total & 1644.81 & & \\
\hline Gas Collection & Weight Before Venting & Weight After Venting & Difference \\
\hline Vent Bag & 320.88 & 346.34 & 25.46 \\
\hline Catch Bottle & 164.25 & 171.19 & 6.94 \\
\hline Total & & & 32.4 \\
\hline Assume gas amount & & & 120.57 \\
\hline Empting of Reactor & Weight Before Empting & Weight After Empting & Difference \\
\hline Catch Bucket & 120.73 & 1638.14 & 1517.41 \\
\hline Paper Towels & 15.41 & 22.24 & 6.83 \\
\hline Total & & & 1524.24 \\
\hline \multicolumn{4}{|l|}{ Material Balance } \\
\hline Gas Weight & 120.57 & & \\
\hline Solid and Liquid Weight & 1524.24 & & \\
\hline Total & 1644.81 & & \\
\hline Separation of Liquid and Solid & Weight Before & Weight After & Difference \\
\hline Liquid Bucket & 135.74 & 1491.88 & 1356.14 \\
\hline Screen & 41.2 & 49.46 & 8.26 \\
\hline Solids Bucket & 120.73 & 273.74 & 153.01 \\
\hline Total & & & 1517.41 \\
\hline Liquid Separation & Weight Before & Weight After & Difference \\
\hline Extender Beaker & 461.5 & 1182.47 & 720.97 \\
\hline Water Beaker & 429.26 & 1040.34 & 611.08 \\
\hline Vacuum Flask & 622.81 & 1162.47 & 539.66 \\
\hline Filter for Gray Solid & 108.81 & 180.23 & 71.42 \\
\hline Crystal Collection & Weight Before Drying & Weight After Drying & Difference \\
\hline Pan and Water & 720.01 & 219.21 & 500.8 \\
\hline \multicolumn{4}{|c|}{ Dried Aqueous Phase rinsed with Methanol and Crystals Collected } \\
\hline & Weight Before & Weight After & \\
\hline Vial for Crystals & 126.34 & 132.67 & 6.33 \\
\hline Amount Evaporated or Rinsed off & 533.33 & & \\
\hline \multicolumn{4}{|l|}{ Solid Separation } \\
\hline \multicolumn{4}{|l|}{ THF Rinse } \\
\hline \multirow[t]{2}{*}{ Amount of THF Added } & 249.16 & & \\
\hline & Weight Before & Weight After Difference & \\
\hline Vacuum Flask & 623.54 & 932.59 & 309.05 \\
\hline Filter and Solids & 109.5 & 202.62 & 93.12 \\
\hline THF Soluble & 59.89 & & \\
\hline THF Insoluble Dried & 54.23 & & \\
\hline Amount of Volatiles & 38.89 & & \\
\hline All weights shown in grams. & & & \\
\hline
\end{tabular}




\begin{tabular}{|c|c|c|c|}
\hline Reactants & & & \\
\hline Hog Manure & 500.14 & & \\
\hline Water & 302.88 & & \\
\hline Propanol & 200.27 & & \\
\hline Diesel Fuel & 626.06 & & \\
\hline Total & 1629.35 & & \\
\hline Gas Collection & Weight Before Venting & Weight After Venting & Difference \\
\hline Vent Bag & 320.99 & 335.93 & 14.94 \\
\hline Catch Bottle & 176.98 & 187.41 & 10.43 \\
\hline Total & & & 25.37 \\
\hline Assume gas amount & & & 178.53 \\
\hline Empting of Reactor & Weight Before Empting & Weight After Empting & Difference \\
\hline Catch Bucket & 136.7 & 1579.16 & 1442.46 \\
\hline Paper Towels & 15.18 & 23.54 & 8.36 \\
\hline Total & & & 1450.82 \\
\hline Material Balance & & & \\
\hline Gas Weight & 178.53 & & \\
\hline Solid and Liquid Weight & 1450.82 & & \\
\hline Total & 1629.35 & & \\
\hline Separation of Liquid and Solid & Weight Before & Weight After & Difference \\
\hline Liquid Bucket & 137.16 & 1432.04 & 1294.88 \\
\hline Screen & 41.82 & 67.99 & 26.17 \\
\hline Solids Bucket & 136.7 & 258.11 & 121.41 \\
\hline Total & & & 1442.46 \\
\hline Liquid Separation & Weight Before & Weight After & Difference \\
\hline Extender Beaker & 433.27 & 1221.8 & 788.53 \\
\hline Water Beaker & 429.26 & 897.55 & 468.29 \\
\hline Vacuum Flask & 622.66 & 1006.78 & 384.12 \\
\hline Filter for Gray Solid & 110.3 & 194.47 & 84.17 \\
\hline Crystal Collection & Weight Before Drying & Weight After Drying & Difference \\
\hline Pan and Water & 773.88 & 430.93 & 342.95 \\
\hline Dried Aqueous Phase rinsed with 1 & thanol and Crystals Colle & ected & \\
\hline & Weight Before & Weight After & \\
\hline Vial for Crystals & 391.03 & 398.27 & 7.24 \\
\hline Amount Evaporated or Rinsed off & 376.88 & & \\
\hline Solid Separation & & & \\
\hline THF Rinse & & & \\
\hline Amount of THF Added & 67.03 & & \\
\hline & Weight Before & Weight After Difference & \\
\hline Vacuum Flask & 732.65 & 838.75 & 106.1 \\
\hline Filter and Solids & 110.3 & 192.6 & 82.3 \\
\hline THF Soluble & 39.07 & & \\
\hline THF Insoluble Dried & 74.78 & & \\
\hline Amount of Volatiles & 7.56 & & \\
\hline All weights shown in grams. & & & \\
\hline
\end{tabular}




\begin{tabular}{|c|c|c|c|}
\hline \multicolumn{4}{|l|}{ Reactants } \\
\hline Hog Manure & 500.03 & & \\
\hline Water & 300.07 & & \\
\hline 2-Propanol & 202.96 & & \\
\hline Diesel Fuel & 789.7 & & \\
\hline Total & 1792.76 & & \\
\hline Gas Collection & Weight Before Venting & Weight After Venting & Difference \\
\hline Vent Bag & 347.72 & 359.82 & 12.1 \\
\hline Catch Bottle & 228.85 & 235.36 & 6.51 \\
\hline Total & & & 18.61 \\
\hline Assume gas amount & & & 135.76 \\
\hline Empting of Reactor & Weight Before Empting & Weight After Empting & Difference \\
\hline Catch Bucket & 144.52 & 1792.57 & 1648.05 \\
\hline Paper Towels & 19.36 & 28.31 & 8.95 \\
\hline Total & & & 1657 \\
\hline \multicolumn{4}{|l|}{ Material Balance } \\
\hline Gas Weight & 135.76 & & \\
\hline Solid and Liquid Weight & 1657 & & \\
\hline Total & 1792.76 & & \\
\hline Separation of Liquid and Solid & Weight Before & Weight After & Difference \\
\hline Liquid Bucket & 144.02 & 1628.7 & 1484.68 \\
\hline Screen & 42.26 & 61.27 & 19.01 \\
\hline Solids Bucket & 249.24 & 393.6 & 144.36 \\
\hline \multicolumn{4}{|r|}{1648.05} \\
\hline Liquid Separation & Weight Before & Weight After & Difference \\
\hline Extender Beaker & 872.6 & 1754.9 & 882.3 \\
\hline Water Beaker & 380 & 957.7 & 577.7 \\
\hline Vacuum Flask & 620.9 & 1121.9 & 501 \\
\hline Filter for Gray Solid & 220 & 296.7 & 76.7 \\
\hline \multicolumn{4}{|l|}{ Solid Separation } \\
\hline \multicolumn{4}{|l|}{ THF Rinse } \\
\hline \multirow[t]{2}{*}{ Amount of THF Added } & 159.41 & & \\
\hline & Weight Before & Weight After Difference & \\
\hline Vacuum Flask & 723 & 942.1 & 219.1 \\
\hline Filter and Solids & 108.33 & 193 & 84.67 \\
\hline THF Soluble & 59.69 & & \\
\hline THF Insoluble Dried & 63.2 & & \\
\hline Amount of Volatiles & 21.47 & & \\
\hline All weights shown in grams. & & & \\
\hline
\end{tabular}




\begin{tabular}{|c|c|c|c|}
\hline \multicolumn{4}{|l|}{ Reactants } \\
\hline Hog Manure & 500.08 & & \\
\hline Water & 300.22 & & \\
\hline Butanol & 200.82 & & \\
\hline Diesel Fuel & 656.73 & & \\
\hline Total & 1657.85 & & \\
\hline Gas Collection & Weight Before Venting & Weight After Venting & Difference \\
\hline Vent Bag & 347.05 & 360.75 & 13.7 \\
\hline Catch Bottle & 217.87 & 229.39 & 11.52 \\
\hline Total & & & 25.22 \\
\hline Assume gas amount & & & 100.4 \\
\hline Empting of Reactor & Weight Before Empting & Weight After Empting & Difference \\
\hline Catch Bucket & 144.18 & 1691.4 & 1547.22 \\
\hline Paper Towels & 25.54 & 35.77 & 10.23 \\
\hline Total & & & 1557.45 \\
\hline \multicolumn{4}{|l|}{ Material Balance } \\
\hline Gas Weight & 100.4 & & \\
\hline Solid and Liquid Weight & 1557.45 & & \\
\hline Total & 1657.85 & & \\
\hline Separation of Liquid and Solid & Weight Before & Weight After & Difference \\
\hline Liquid Bucket & 144.12 & 1490.6 & 1346.48 \\
\hline Screen & 41.48 & 59.06 & 17.58 \\
\hline Solids Bucket & 215.51 & 398.67 & 183.16 \\
\hline \multicolumn{4}{|r|}{1547.22} \\
\hline Liquid Separation & Weight Before & Weight After & Difference \\
\hline Extender Beaker & 438.1 & 1377.6 & 939.5 \\
\hline Water Beaker & 536.1 & 930.6 & 394.5 \\
\hline Vacuum Flask & 620.7 & 1010.1 & 389.4 \\
\hline Filter for Gray Solid & 110.3 & 115.4 & 5.1 \\
\hline \multicolumn{4}{|l|}{ Solid Separation } \\
\hline \multicolumn{4}{|l|}{ THF Rinse } \\
\hline \multirow[t]{2}{*}{ Amount of THF Added } & 301.57 & & \\
\hline & Weight Before & Weight After Difference & \\
\hline Vacuum Flask & 720.3 & 1072.9 & 352.6 \\
\hline Filter and Solids & 110.5 & 264.9 & 154.4 \\
\hline THF Soluble & 51.03 & & \\
\hline THF Insoluble Dried & 77.4 & & \\
\hline Amount of Volatiles & 54.73 & & \\
\hline All weights shown in grams. & & & \\
\hline
\end{tabular}




\begin{tabular}{|c|c|c|c|}
\hline \multicolumn{4}{|l|}{ Reactants } \\
\hline Hog Manure & 500.35 & & \\
\hline Water & 300.84 & & \\
\hline S-Butanol & 205.47 & & \\
\hline Diesel Fuel & 643.89 & & \\
\hline Total & 1650.55 & & \\
\hline Gas Collection & Weight Before Venting & Weight After Venting & Difference \\
\hline Vent Bag & 345.64 & 363.22 & 17.58 \\
\hline Catch Bottle & 232.03 & 235.44 & 3.41 \\
\hline Total & & & 20.99 \\
\hline Assume gas amount & & & 103.01 \\
\hline Empting of Reactor & Weight Before Empting & Weight After Empting & Difference \\
\hline Catch Bucket & 144.1 & 1679.54 & 1535.44 \\
\hline Paper Towels & 19.17 & 31.27 & 12.1 \\
\hline Total & & & 1547.54 \\
\hline \multicolumn{4}{|l|}{ Material Balance } \\
\hline Gas Weight & 103.01 & & \\
\hline Solid and Liquid Weight & 1547.54 & & \\
\hline Total & 1650.55 & & \\
\hline Separation of Liquid and Solid & Weight Before & Weight After & Difference \\
\hline Liquid Bucket & 144.44 & 1544.18 & 1399.74 \\
\hline Screen & 42.1 & 63.68 & 21.58 \\
\hline Solids Bucket & 192.53 & 306.65 & 114.12 \\
\hline \multicolumn{4}{|r|}{1535.44} \\
\hline Liquid Separation & Weight Before & Weight After & Difference \\
\hline Extender Beaker & 874.38 & 1741.5 & 867.12 \\
\hline Water Beaker & 380.54 & 897.25 & 516.71 \\
\hline Vacuum Flask & 625 & 1055.4 & 430.4 \\
\hline Filter for Gray Solid & 109.9 & 196.21 & 86.31 \\
\hline \multicolumn{4}{|l|}{ Solid Separation } \\
\hline \multicolumn{4}{|l|}{ THF Rinse } \\
\hline \multirow[t]{2}{*}{ Amount of THF Added } & 134.88 & & \\
\hline & Weight Before & Weight After Difference & \\
\hline Vacuum Flask & 468.1 & 662 & 193.9 \\
\hline Filter and Solids & 108.9 & 164 & 55.1 \\
\hline THF Soluble & 59.02 & & \\
\hline THF Insoluble Dried & 40.02 & & \\
\hline Amount of Volatiles & 15.08 & & \\
\hline All weights shown in grams. & & & \\
\hline
\end{tabular}




\begin{tabular}{|c|c|c|c|}
\hline \multicolumn{4}{|l|}{ Reactants } \\
\hline Hog Manure & 500.21 & & \\
\hline Water & 300.2 & & \\
\hline T-Butanol & 200.11 & & \\
\hline Diesel Fuel & 700.96 & & \\
\hline Total & 1701.48 & & \\
\hline Gas Collection & Weight Before Venting & Weight After Venting & Difference \\
\hline Vent Bag & 345.9 & 373.67 & 27.77 \\
\hline Catch Bottle & 232.59 & 234.54 & 1.95 \\
\hline Total & & & 29.72 \\
\hline Assume gas amount & & & 144.91 \\
\hline Empting of Reactor & Weight Before Empting & Weight After Empting & Difference \\
\hline Catch Bucket & 144.41 & 1686.12 & 1541.71 \\
\hline Paper Towels & 19.34 & 34.2 & 14.86 \\
\hline Total & & & 1556.57 \\
\hline \multicolumn{4}{|l|}{ Material Balance } \\
\hline Gas Weight & 144.91 & & \\
\hline Solid and Liquid Weight & 1556.57 & & \\
\hline Total & 1701.48 & & \\
\hline Separation of Liquid and Solid & Weight Before & Weight After & Difference \\
\hline Liquid Bucket & 144.6 & 1518.9 & 1374.3 \\
\hline Screen & 41.68 & 60.5 & 18.82 \\
\hline Solids Bucket & 181.41 & 330 & 148.59 \\
\hline \multicolumn{4}{|r|}{1541.71} \\
\hline Liquid Separation & Weight Before & Weight After & Difference \\
\hline Extender Beaker & 874.5 & 1701.1 & 826.6 \\
\hline Water Beaker & 380.7 & 899.4 & 518.7 \\
\hline Vacuum Flask & 468.1 & 907.6 & 439.5 \\
\hline Filter for Gray Solid & 108.4 & 187.6 & 79.2 \\
\hline \multicolumn{4}{|l|}{ Solid Separation } \\
\hline \multicolumn{4}{|l|}{ THF Rinse } \\
\hline \multirow[t]{2}{*}{ Amount of THF Added } & 130.94 & & \\
\hline & Weight Before & Weight After Difference & \\
\hline Vacuum Flask & 719.9 & 852.9 & 133 \\
\hline Filter and Solids & 110.4 & 256.99 & 146.59 \\
\hline THF Soluble & 2.06 & & \\
\hline THF Insoluble Dried & 93.89 & & \\
\hline Amount of Volatiles & 52.64 & & \\
\hline All weights shown in grams. & & & \\
\hline
\end{tabular}

